
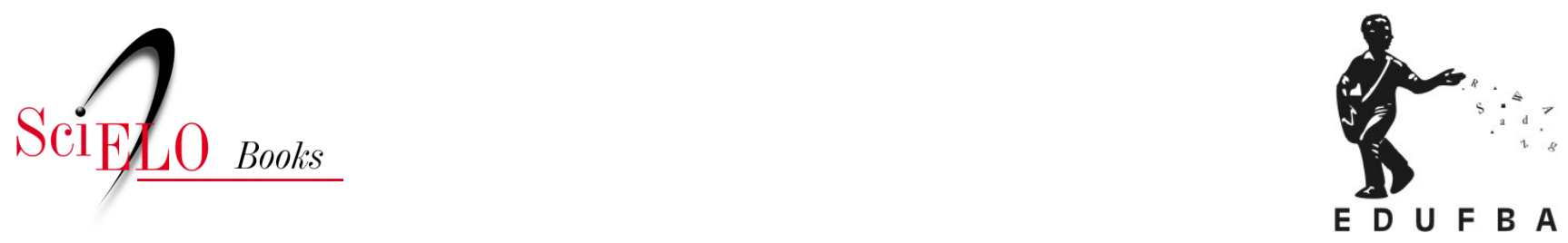

\title{
Práticas e redes colaborativas para inovação nos INCTs da área de nanotecnologia
}

\author{
Valdinéia Barreto Ferreira
}

\section{SciELO Books / SciELO Livros / SciELO Libros}

FERREIRA, V.B. Institutos nacionais de ciência e tecnologia de nanotecnologia. In: E-science e politicas públicas para ciência, tecnologia e inovação no Brasil [online]. Salvador: EDUFBA, 2018, pp. 139-203. ISBN: 978-85-232-1865-2. https://doi.org/10.7476/9788523218652.0009.

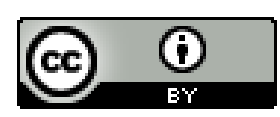

All the contents of this work, except where otherwise noted, is licensed under a Creative Commons Attribution $\underline{4.0 \text { International license. }}$

Todo o conteúdo deste trabalho, exceto quando houver ressalva, é publicado sob a licença Creative Commons Atribição 4.0. 


\section{PRÁTICAS E REDES COLABORATIVAS PARA INOVAÇÃO NOS INCTS DA ÁREA DE NANOTECNOLOGIA}

As práticas colaborativas desenvolvidas nos diversos campos científicos repercutem na manutenção de uma atividade de excelência. Influenciam ainda, na produção e fornecimento da informação científica, tecnológica e de inovação em uma sociedade diferenciada, a qual sofre os efeitos das transformações tecnológicas, político-institucionais e de inovação.

Essas práticas são ainda atividades científicas realizadas pelos pesquisadores que demandam um aparato científico e tecnológico adequado para que sua realização forneça os insumos esperados. Conforme Albagli e colaboradores (2013) as práticas colaborativas contemporâneas são "expressas em noções tais como: redes de conhecimento, coinovação, cocriação, produção peer-to-peer, crowdsourcing, inovação aberta, inovação social, open Science, entre outras, cada qual com seu significado específico".

Os ambientes digitais contemporâneos desenvolvidos com o boom tecnológico favorecem a realização das práticas colaborativas e se constituem no diferencial que as distingue das práticas tradicionais. A busca pelo entendimento concreto sobre essas práticas e sua efetiva ocorrência nos INCTs da área de Nanotecnologia originou a seguinte questão da pesquisa: quais são as práticas científicas colaborativas para inovação realizadas e as redes colaborativas existentes nos institutos da área de Nanotecnologia? Respondê-la foi um dos objetivos específicos propostos e contemplados na pesquisa que derivou esse livro. 
O objetivo foi respondido e as práticas e redes colaborativas pertinentes ao questionamento identificadas. As práticas mais recorrentes nos institutos foram a formação de recursos humanos e à colaboração científica tradicional, uma evidência de que apesar das inovações tecnológicas que ocorrem na sociedade contemporânea e inserção de novas práticas colaborativas no âmbito acadêmico, a tradição ainda prevalece, acompanhada da preocupação com a formação qualificada de seus pares. As redes colaborativas identificadas foram várias: rede de colaboração dos pesquisadores dos INCTs da área de Nanotecnologia fomentada pela produção científica; a rede das práticas colaborativas como resultado das interações entre os INCTs e os atores e actantes que a compuseram; a rede dos INCTs e artefatos que compuseram a infraestrutura $e$-Science; a rede da cadeia de inovação composta pelas etapas contempladas pelos institutos em suas interações; a rede dos INCTs e as políticas públicas que sustentaram o Programa e seu entorno; a rede das universidades; das instituições; das organizações; dos agentes de fomento; das empresas; dos laboratórios; dos hospitais, e muitas outras identificadas no conglomerado investigado.

As fontes utilizadas foram importantes para analisar os indicadores nesta etapa da investigação, como a colaboração, a internacionalização e a inovação, aspectos pertinentes às atividades colaborativas e subsídios usados para obtenção da resposta que satisfez ao questionamento realizado.

Esta seção foi subdividida em duas subseções que permitiram uma melhor ordenação dos resultados apresentados e analisados. A primeira ateve-se às práticas colaborativas identificadas nos INCTs da área de Nanotecnologia. A segunda ficou com o encargo de apresentar as redes colaborativas identificadas nos INCTs e os atributos que caracterizaram os atores/actantes que formaram o coletivo representado pelos institutos e o seu entorno.

\section{Práticas colaborativas nos INCTs}

A percepção dos pesquisadores dos INCTs acerca das práticas colaborativas iniciou os questionamentos. Essa etapa fez parte de um conjunto de procedimentos que buscavam conhecer, cada vez mais, o perfil dos pesquisadores que representavam a área. 
Quando questionados sobre os modelos cooperativos de produção do conhecimento que conheciam ou com os quais tinham familiaridade, os respondentes sinalizaram as redes de especialistas (37,4\%); as redes de informação (29,7\%); as redes internas de gestão de conhecimento (27,5\%); as redes de conhecimento formal (29,7\%) e as alianças estratégicas (29,7\%). A opção nenhuma das alternativas $(31,9 \%)$ e as comunidades de prática (CoPs) (1\%), as últimas dos modelos cooperativos com o menor percentual de respondentes. O Gráfico 9 ilustrou o resultado analisado.

Gráfico 9 - Modelos cooperativos de produção do conhecimento

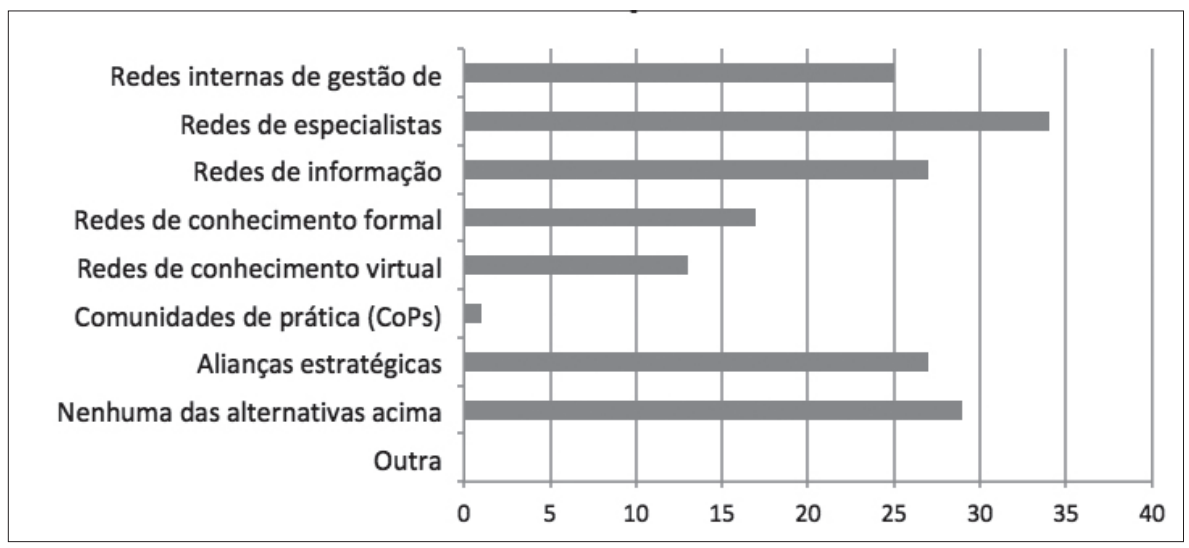

Fonte: Elaboração da autora.

O resultado que contemplou as redes de especialistas como maioria dos respondentes não causou surpresa, considerando-se que os INCTs da área de Nanotecnologia constituem-se, por natureza, em uma rede de especialistas. Entretanto, surpreendeu o percentual de $31 \%$ indicado pelos pesquisadores para nenhuma das alternativas apresentadas. Como entender uma parcela do grupo de pesquisadores, a qual trabalha em redes colaborativas, cujo nível de especialização é alto, conforme contemplado no levantamento da titulação acadêmica, não se enquadrar em nenhum dos modelos cooperativos apresentados?

Ocorreram suposições que pudessem justificar uma ocorrência significativa de pesquisadores que em nenhum dos modelos cooperativos apresentados se enquadram. Dentre essas a de que eles poderiam estar desenvolvendo seu traba- 
lho de modo individual, ou à margem dos institutos, apesar de estarem oficialmente ligados a eles. Isso contradiria a lógica do trabalho proposto pelo Programa dos INCTs que prima pelas redes colaborativas e a composição representada pelos institutos.

Pensou-se ainda que eles pudessem não estar familiarizados com o vocabulário apresentado no questionamento, razão pela qual preferiram não pontuar o que não conheciam. Ou, a despeito de fazerem parte dos modelos apresentados, não estarem preocupados com rótulos ou denominações, o que os faziam assinalar desconhecimento sobre eles. Não foi identificada outra suposição plausível para o resultado.

Ao questionar-se sobre a efetiva colaboração realizada entre os pesquisadores dos INCTs ou colegas da área de atuação obteve-se o resultado pontuado no Gráfico 10.

Gráfico 10 - Colaboração nos INCTs de Nanotecnologia

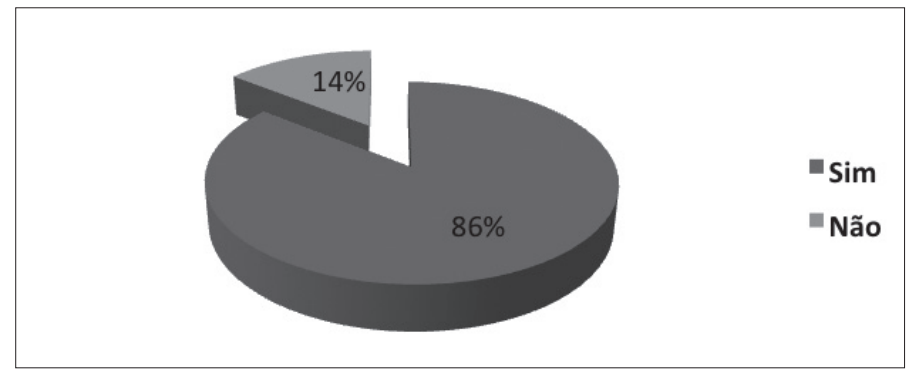

Fonte: Elaboração da autora.

Os pesquisadores responderam, em ampla maioria, que colaboraram ou estão colaborando com os seus pares; a assertiva (85,7\%) e a negativa (14,3\%). Esse resultado é coerente com o perfil da área de Nanotecnologia, considerada altamente colaborativa. Os projetos colaborativos desenvolvidos ou em desenvolvimento, indicados pelos pesquisadores, contemplaram as diversas aplicações que a área realizou e corresponderam às implementações identificadas na literatura científica consultada.

Dentre os projetos pontuados nas respostas fornecidas pelos pesquisadores destacam-se: desenvolvimento de sensores infravermelho; sistemas de computa- 
ção baseados em redes de sensores; síntese de dispositivos de liberação controlada de fármacos e similares; caracterização de grafenos e nanotubos de carbono; marcadores para fins diagnósticos de doenças; encapsulamento optoeletrônico com micro e nanotecnologias; estrutura eletrônica de materiais 2D; desenvolvimento de nanocompósitos para remoção de metais pesados da água;

avaliação de atividades biológicas de frações proteicas de peçonhas, entre muitos outros.

A identificação das práticas colaborativas efetivas desenvolvidas pelos pesquisadores foi objeto de análise em dois grupos de dados empíricos; o resultado do questionário online e da análise de conteúdo do relatório de acompanhamento de projeto.

No questionário online, a pergunta sobre as práticas colaborativas desenvolvidas contemplou a colaboração científica como a mais desenvolvida (85,7\%) pela ampla maioria entre os respondentes; as redes de conhecimento (28,6\%); seguida da cocriação $(20,9 \%)$ e da coinovação $(20,9 \%)$, as duas últimas em mesmo percentual. Obtiveram-se os seguintes percentuais de indicações para produção peer-to-peer (13,2\%), inovação aberta (7,7\%) e a inovação social (4,4\%). A prática de crowdsourcing (1,1\%) apenas das respostas e a opção nenhuma das alternativas (5,5\%). O Gráfico 11 pontuou o resultado identificado.

Gráfico 11 - Práticas colaborativas - Questionário online

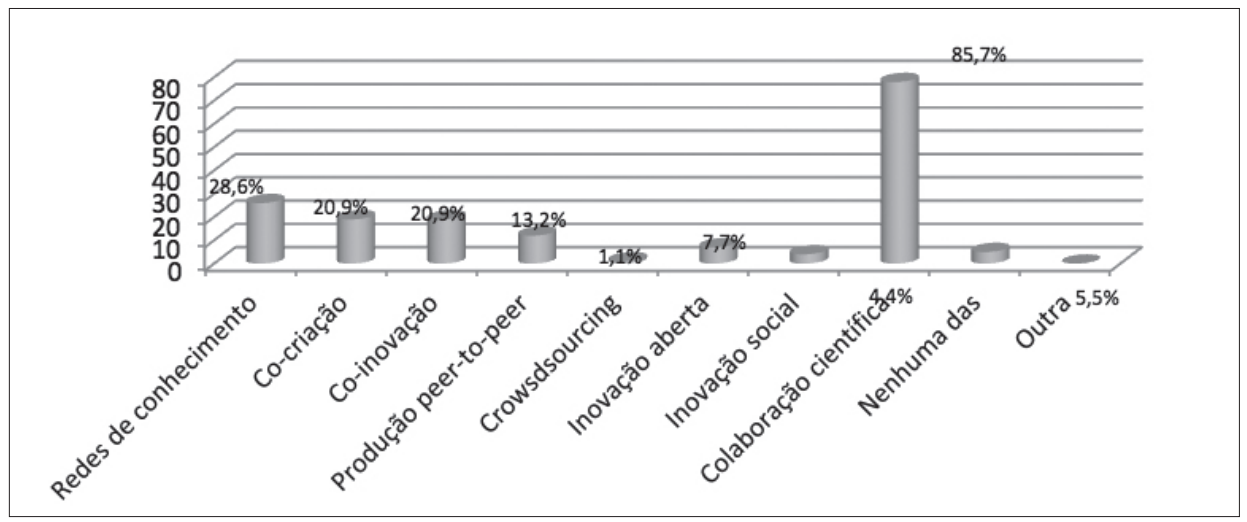

Fonte: Elaboração da autora. 
$\mathrm{Na}$ análise correspondente aos dados dos relatórios de acompanhamento de projeto, os resultados contemplaram as informações provenientes dos INCTs da área de Nanotecnologia selecionados como amostra. As práticas colaborativas identificadas foram relacionadas conforme indicado no relatório. É importante registar que as ocorrências podem ser simultâneas por se tratarem de práticas colaborativas, resultantes de diversos tipos de interações. Em uma parceria colaborativa realizada, pode ocorrer ao mesmo tempo, a colaboração científica, o compartilhamento de recursos, uma consultoria, entre outras. Contudo, para a quantificação, levou-se em consideração os atores envolvidos na interação, as atividades predominantes do grupo em análise e a informação indicada no relatório. O Gráfico 12 contemplou as práticas identificadas.

Gráfico 12 - Práticas colaborativas - Relatórios

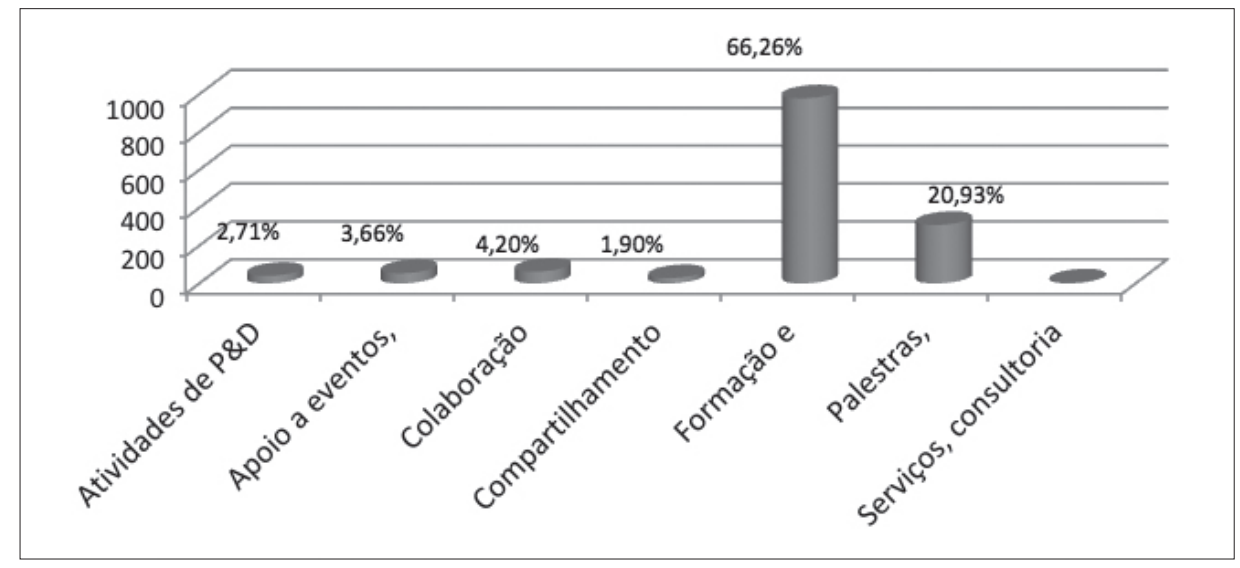

Fonte: Elaboração da autora.

De modo diverso ao que foi contemplado no questionário online, à prática colaborativa mais indicada foi a formação e capacitação de recursos humanos, com o percentual de $66,26 \%$. A segunda mais indicada foi a realização de palestras, conferências, colóquios, seminários etc, com o percentual de 20,93\%; a esse resultado atribui-se a forte atuação dos INCTs na formação e capacitação de recursos humanos. Informações passíveis de corroboração nos resultados que serão apresentados nesta seção, na sequência. 
Entretanto, isto não quer dizer que a prática de colaboração científica, indicada pela maioria dos respondentes do questionário online, esteja fora do contexto. Pelo contrário, o resultado obtido reforça sua presença, pois se existe formação e capacitação de recursos humanos e apresentação de palestras, conferências, colóquios, simpósio, entre outros eventos, a colaboração científica está implícita na atividade. Isso caracteriza evidência de que a tradição ainda prevalece, apesar das inovações tecnológicas que ocorrem na sociedade contemporânea e da inserção de novas práticas colaborativas no âmbito acadêmico

Esse resultado manteve-se em sintonia com as observações pautadas pelos coordenadores dos INCTs nas entrevistas online; quando eles foram questionados sobre as práticas colaborativas realizadas nos institutos e a existência de algum diferencial após o advento das tecnologias de comunicação e informação e da $e$-Science, eles responderam da seguinte forma:

- basicamente nós continuamos desenvolvendo como sempre foi feito, houve alguma melhora nesse sentido, nós temos um site, no site nós colocamos algumas informações e tal [...] nós continuamos no mesmo processo que vinhamos fazendo e que já se sabia fazer. Na forma tradicional basicamente;

- [...] nem um nem outro, nós gradualmente vamos incorporando e usando mais as ferramentas. Creio que as ferramentas estão melhores e algumas não avançaram nesse aspecto. Portanto, nós usamos a ferramenta que temos, porque não temos muito acesso. Então acho que gradualmente vai aumentando essa utilização;

- [...] se houve mudança foi pequena, é claro que sempre tem as pessoas que interagem com essas ferramentas, mas na minha opinião, na minha avaliação que é assim, é qualitativa e não quantitativa, porque eu não tenho os números para te passar aqui...mas na minha avaliação essas ferramentas por enquanto, contribuíram pouco na colaboração. Acho que o encontro presencial através dos encontros anuais foram mais efetivos que essas ferramentas;

- no caso da parte colaborativa o que essas novas tecnologias auxiliam é na comunicação propriamente dita. E nós podemos estar em contato direto por Skype praticamente diariamente com todos os grupos que estão espalhados pelo país. Nós queremos mostrar os resultados e discutir os resultados, colocamos no Skype compartilhamos a tela e podemos promover aquela discussão sem a necessidade de deslocamento. Isso na realidade 
acelera o processo da pesquisa, porque você consegue discutir de uma forma mais eficaz, mais rápida;

- então na minha opinião, em termos de colaboração dentro do âmbito do INCT eu senti que foi mais efetiva o encontro presencial, os encontros anuais, surgiram muitas colaborações nesses encontros mais do que nessas ferramentas, nesses sites.

Inferiu-se, com os resultados obtidos, que os pesquisadores dos institutos consultados desenvolvem práticas colaborativas, contudo, a realizam na maioria das vezes, de forma tradicional. Apesar dos recursos tecnológicos presentes na sociedade contemporânea e das práticas colaborativas desenvolvidas em ambientes virtuais, os pesquisadores analisados indicaram que desenvolvem a colaboração científica tradicional e utilizam os recursos tecnológicos mais efetivamente, nas comunicações virtuais realizadas.

Ao utilizarem os recursos tecnológicos nas suas atividades científicas, os pesquisadores o fazem, mas não de modo acentuado. Apesar de serem pesquisadores da alta tecnologia, utilizam-na em suas práticas de forma moderada. Os recursos colaborativos virtuais utilizados, em sua maioria, resumem-se a artefatos para comunicação como correio eletrônico, plataformas virtuais para videoconferência ou conversas online, a exemplo do software Skype e sistemas internos desenvolvidos no âmbito do instituto, como o webcs.

As outras formas de práticas colaborativas pontuadas pelos pesquisadores não obtiveram um percentual que permitisse situar o grupo investigado como grandes utilizadores de dispositivos produzidos para ambientes colaborativos virtuais. Apesar da prática de produção peer-to-peer (P2P) ter obtido o percentual de $13,2 \%$, essa ainda é pouco significativa dentro de uma comunidade que possui um perfil de pesquisadores envolvidos com a alta tecnologia. O crowdsourcing, o qual conforme Oliveira (2012, p. 1), "é um modelo de criação coletiva e em massa, cuja essência é a cooperação entre os participantes”, obteve o percentual irrisório de apenas $1,1 \%$.

Entretanto, ao se fazer um recorte do resultado e analisar os INCTs selecionados na amostra, pode-se perceber que as práticas colaborativas mais frequentes, realizadas especialmente entre institutos de ciência e tecnologia, universidades e empresas fizeram-se presentes nos INCTs. Ao se destacar as práticas realiza- 
das com maior frequência pelos institutos constatou-se que no NAMITEC, NANOBIOTECNOLOGIA e NANOCARBONO o registro da predominância for formação e capacitação de recursos humanos. Nesses institutos identificou-se a realização de quase todas as práticas. De modo geral, a menos contemplada foi a realização de consultorias.

Nos INCTs, registrou-se uma ocorrência simultânea de muitas atividades, apesar de a formação e capacitação de recursos humanos ter sido o "carro-chefe". A colaboração científica esteve presente em todos os INCTs, conforme se pode constatar no Gráfico 13.

Gráfico 13 - Atividades colaborativas mais recorrentes

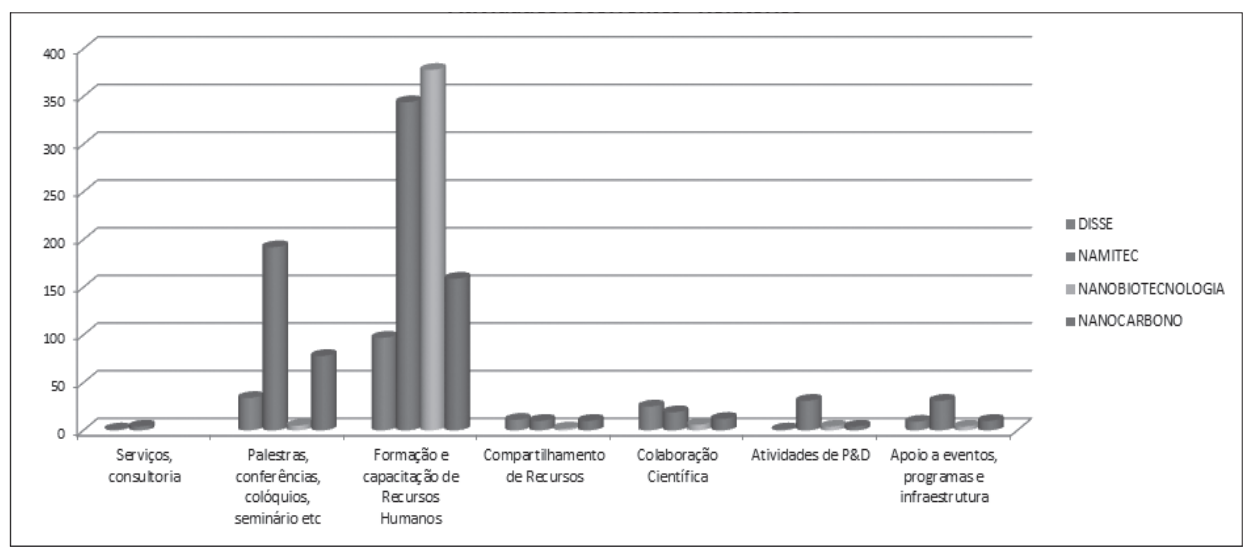

Fonte: Elaboração da autora.

Com a identificação dos modelos cooperativos conhecidos, confirmação da realização da colaboração pelos pesquisadores, identificação das práticas desenvolvidas, o próximo questionamento foi sobre os benefícios esperados com a colaboração realizada.

O compartilhamento de recursos financeiros e suporte à infraestrutura de pesquisa foi o benefício que obteve o maior percentual de indicações, com 81,3\% das respostas. Levando-se em consideração o momento de crise econômica e política por que passa o país, esse foi um benefício sinalizado e utilizado de modo amplo pelos pesquisadores. Essa foi a alternativa encontrada para não perder esforços empreendidos no desenvolvimento de pesquisas e criar bases cada 
vez mais sólidas entre os parceiros conquistados. Este resultado foi apresentado no Gráfico 14.

Os demais benefícios esperados com as práticas colaborativas foram pontuados com os seguintes percentuais: aumento da qualidade e visibilidade da pesquisa (76,9\%); transferência de conhecimento e habilidades (73,6\%); participação em grandes projetos (69,2\%); formação de novos pesquisadores $(68,1 \%)$; e contribuição para o rápido crescimento do conhecimento científico $(57,1 \%)$.

\section{Gráfico 14 - Práticas colaborativas - Benefícios}

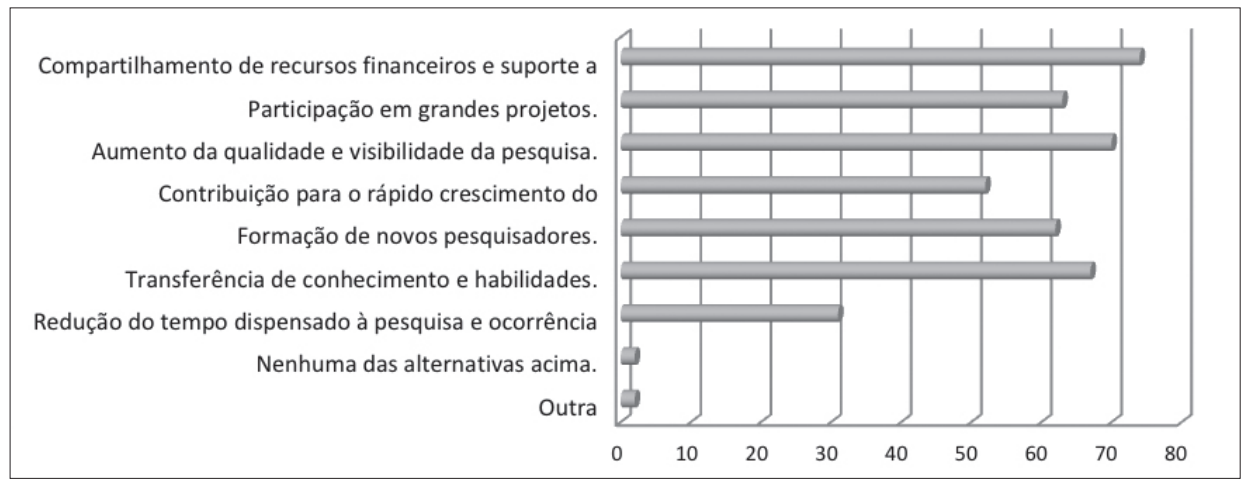

Fonte: Elaboração da autora.

A expectativa em torno dos benefícios proporcionados pelas práticas colaborativas foi confirmada de acordo com a necessidade premente das instituições for financiamento e recursos. Os coordenadores dos institutos expressaram de modo pontual suas opiniões sobre o compartilhamento de recursos de modo pontual, conforme trechos das entrevistas online destacados e apresentados abaixo.

sem a rede, cada um ficaria fechado no seu laboratório e dessa forma nos comunicamos muito mais e fazemos trabalhos conjunto e aumentamos a produtividade de todos. Inclusive, sobretudo o acesso a equipamentos, nós usamos equipamentos que são dispendiosos, caros e a rede permite acesso a vários membros da rede;

[...] a colaboração, ela surge a partir do momento que você poe dinheiro, basicamente você tem que dar recursos. Eu não tenho o número de cabeça, mas foram centenas de viagens de pesquisadores e estudantes para fazer este tipo de 
coisa. E a terceira maneira de você colaborar é você criar... você ter equipamento multiusuário, está certo? Ao invés de você ter o mesmo equipamento em vários lugares diferentes, você tem um equipamento no centro, que faz parte do instituto e que é um equipamento multiusuário e que você disponibiliza recursos para que qualquer pessoa possa ir fazer uma viagem naquele instituto, o equipamento é do grupo como um todo;

[...] exatamente porque o Brasil é um país onde não se tem tantos recursos assim. Então nós temos que usar de forma otimizada os recursos;

Os depoimentos obidos corroboraram com o resultado de que o compartilhamento de recursos financeiros e o suporte a infraestrutura de pesquisa são os maiores benefícios obtidos com a realização das práticas colaborativas.

Os problemas e/ou obstáculos enfrentados durante o desempenho das práticas colaborativas foi o alvo do questionamento seguinte. Os pesquisadores sinalizaram em sua maioria, para o percentual de 60,4\%, para os recursos financeiros insuficientes e/ou cancelamento da manutenção do projeto pela agência de fomento. O Gráfico 15 pontuou o resultado obtido.

Gráfico 15 - Práticas Colaborativas - Problemas/obstáculos enfrentados

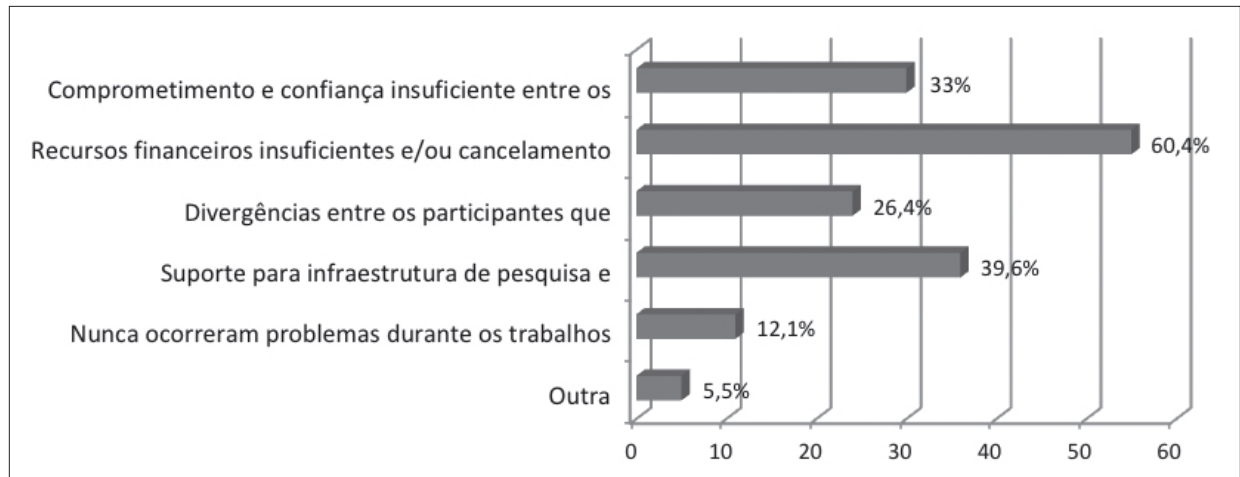

Fonte: Elaboração da autora.

Essa resposta que refletiu a expectativa e ansiedade dos pesquisadores e coordenadores dos INCTs durante a vigência do Programa, em alguns momentos da primeira fase, período contemplado nesta pesquisa. Um estado de espíri- 
to passível de ser captado durante os relatos colhidos nas entrevistas realizadas pela pesquisadora.

A demora ocasionada pelo repasse das verbas, a imprevisibilidade da continuidade do Programa INCT e o período que antecedeu a divulgação da Chamada INCT - MCTI/CNPQ/CAPES/FAPS No 16/2014 (CNPq, 2014a) prevista para sair a partir de 6 março de 2015 e somente divulgada em 11 de maio de 2016, caracterizaram muito bem o momento. $\mathrm{O}$ atraso de mais de um ano na divulgação do resultado provocou nos coordenadores dos INCTs a expectativa vivenciada durante o processo, conforme os trechos selecionados da entrevista online e apresentados logo a seguir.

[...] por exemplo o meu INCT em particular terminou no início desse ano, encerrou, e já encerrou com um pouco de atraso porque nós tivemos que fazer aditamento. Acabaram os recursos e ficamos esperando. A avaliação. do outro vai demorar $e$ então vamos ficar mais de um ano, um ano e meio sem ter os recursos. O que acontece em um ano e meio, as equipes se desarticulam e todo esse processo colaborativo vai por água abaixo. Ai depois você tem que investir e começar do zero. Esta bom que não seja do zero mas tem que recomeçar

com certeza compromete, nós estamos em uma fase onde já deveríamos estar com nova resposta do MCT, com novo projeto neste momento e então todas as decisões estão sendo todas prorrogadas, quer dizer postergadas. Então isso prejudica os INCTs, isso é bastante preocupante, essa demora nessa fase;

está muito atrasado, na verdade é preocupante, bastante preocupante porque essa resposta deveria ter saído em maio, foi adiado para outubro e agora foi adiado sem data definida. Estão falando em julho de 2016 e tal, mas isso signifique que não tem recurso em 2016, porque até ser realizada a chamada, assinar toda burocracia etc etc e o resultado sair, eu não conto com esse recurso antes do final de 2016. [...] Provavelmente vai ter um gap ai e mesmo que esse gap seja pequeno, ele é um gap importante porque as pessoas se desmobilizam. Na realidade eu já estou sentindo uma certa desmobilização dentro do INCT por falta de recursos. O recurso vai acabando, ai as pessoas não tem mais como se deslocar, não tem interesse.... obviamente sem recurso o interesse diminuiu, cada um vai buscar o seu e vira cada um por si e Deus por todos. Então é preocupante, muito preocupante;

[...] o edital era para ser julgado em 2015, mas já foi empurrado para 2016. Bom na verdade a comunidade científica está muito pessimista com relação ao que vai acontecer. Um programa importante como este deveria continuar, agora eu para The ser muito franco, tenho cá minhas dúvidas se realmente esse governo vai dar continuidade a este programa, no nivel do que foi o da primeira chamada; 
eu acho escandaloso, eu acho escandaloso cada vez que contam uma história diferente, um motivo pelo qual está sendo adiado [...] na realidade a mais de um ano que estão adiando, adiando e adiando e sabe Deus quando que de fato vai ter recursos.

Os relatos ilustraram que o problema/obstáculo predominante entre as práticas colaborativas é resultado da qualidade da gestão das agências de fomento, empreênciada às políticas púbicas, a qual compromete de modo acentuado a manutenção dessas práticas realizadas nos INCTs.

Um problema recorrente em projetos e políticas mantidos pelo governo e cercados por atrasos no repasse das verbas e falta de continuidade. A dependência financeira de fontes governamentais são as principais causas desse tipo de problema e registrou-se a preocupação com a desarticulação do grupo causada pelos atrasos no repasse dos recursos. Esse elemento compromete um trabalho realizado durante anos e favorece a perda de conquistas obtidas no desenvolvimento de práticas colaborativas.

Uma alternativa para minimizar essa situação foi justamente encontrada nas parcerias colaborativas que puderam ser realizadas fora da esfera governamental, entre os INCTs e os outros atores institucionais como empresas, organizações e instituições privadas. Essa alternativa funcionou como um recurso para minimizarem os problemas financeiros provenientes dos atrasos com o repasse de verbas para manutenção das pesquisas. A atividade foi identificada nas parcerias realizadas pelos institutos e sinalizada nos resultados coletados referentes às redes colaborativas para inovação.

Identificou-se um grande problema/obstáculo para a manutenção das práticas colaborativas e alternativas e sugestões para a solução e facilidades no processo de colaboração composeram a temática do questionamento seguinte, dirigido aos pesquisadores. O resultado obtido evidenciou a relação entre o problema/obstáculo indicado como prioritário, nos parágrafos anteriores e as sugestões para sua resolução. A solução indicada pela maioria dos respondentes indicada pela maioria dos respondentes para facilitar a colaboração foi a manutenção dos recursos financeiros e suporte à infraestrutura de pesquisa pelas agências de fomento, com $76,9 \%$ das indicações. 
Esse resultado enfatizou a grande preocupação dos pesquisadores da área em relação à manutenção dos recursos financeiros por parte das agências de fomento, os quais enfrentam cotidianamente os problemas derivados da gestão realizada. A infraestrutura de pesquisa compatível com o avanço tecnológico obteve $68,1 \%$ de indicações, a refletir que os pesquisadores da área querem ter a sua disposição os recursos tecnológicos mais atualizados para o desempenho de suas práticas, apesar de a utilização das tecnologias não ser realizada de modo pleno. O Gráfico 16 apresentou o resultado obtido.

Gráfico 16 - Sugestões para facilitar a colaboração

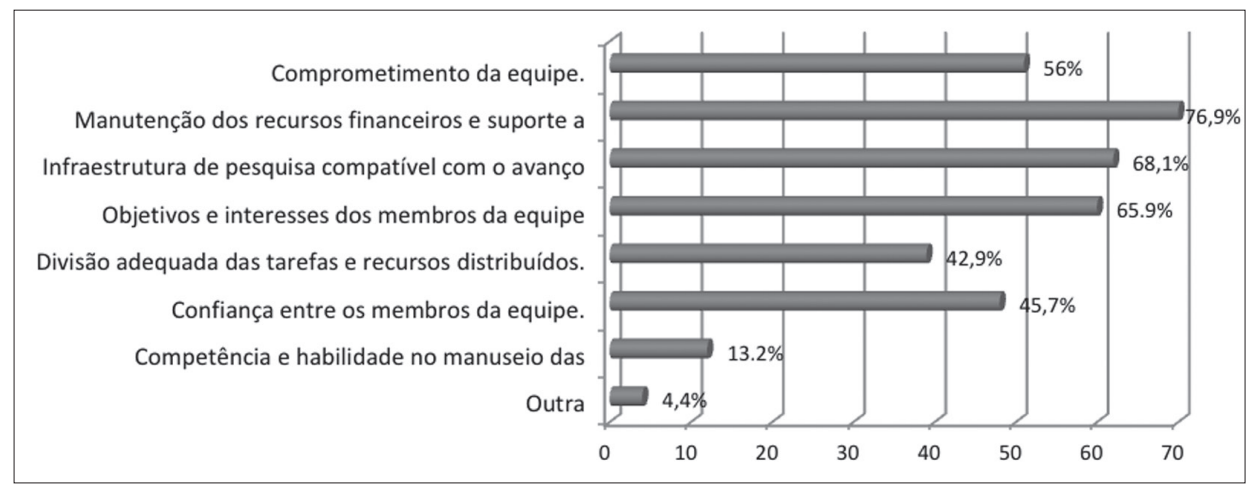

Fonte: Elaboração da autora.

Os objetivos e interesses alinhados, confiança entre os membros da equipe e divisão adequada das tarefas e recursos distribuídos corresponderam a sugestões cujos percentuais indicram preocupação com o ambiente no qual ocorrem as práticas colaborativas.

A internacionalização das práticas colaborativas foi a faceta da colaboração que permeou o questionamento realizado na sequência, esteve presente na análise da produção científica e foi o indicador contemplado nos resultados apresentados. Registrou-se o percentual de $78 \%$, para a afirmativa em relação à realização de práticas colaborativas no exterior, coerente com o número de trabalhos publicados na mesma abrangência geográfica e identificados na análise da produção científica neste capítulo. 
A área das ciências exatas, identificada no perfil dos pesquisadores como a predominante nos INCTs, são consideradas como "áreas onde a colaboração científica com parceiros internacionais é um mecanismo de redução de custos, uma vez que a implantação de alguns equipamentos e técnicas pode custar muito à agência local." (LETA; CRUZ, 2003, p. 154).

A identificação da internacionalização das práticas colaborativas dos pesquisadores dos institutos foi um resultado positivo, considerando-se os objetivos pretendidos pelo Programa INCTs, de impulsionar a pesquisa científica básica e fundamental e torná-la competitiva internacionalmente. O resultado visualizado no Gráfico 17 confirmou a prevalência dessa prática na esfera internacional.

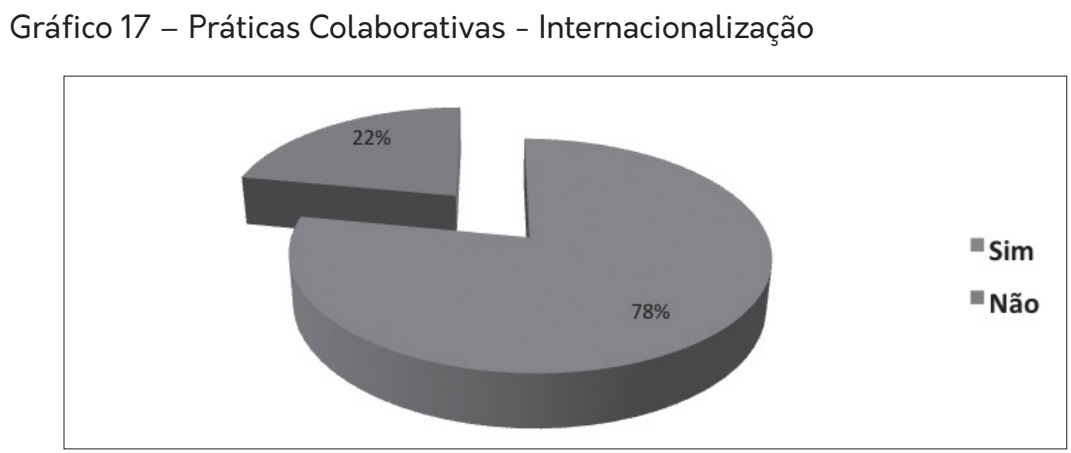

Fonte: Elaboração da autora.

A apresentação dos resultados e discussão sobre a percepção acerca da colaboração e suas práticas continuou nos parágrafos seguintes desta seção. A área da Nanotecnologia caracteriza-se como um domínio multidisciplinar coberto por pesquisadores dos mais diversos campos do conhecimento. Esses contribuem com suas expertises em prol do desenvolvimento de aplicações as mais variadas e convertidas em benefícios para a sociedade. Os INCTs de Nanotecnologia não fugiram a essa regra, conforme ficou comprovado na identificação do perfil dos pesquisadores dos institutos.

As redes de práticas colaborativas para inovação forneceram a formação mais adequada para o tipo de relacionamento ensejado no domínio da Nanotecnologia. Escalante Ludeña (2008, p. 17) ressalta ainda que "como a nanotecnologia envolve muitas áreas do conhecimento, para ser desenvolvida precisa de 
um trabalho multidisciplinar onde interajam muitos atores com suas diversas competências, surgindo assim à necessidade de redes de inovação.” Os resultados pertinentes à inovação associados às práticas colaborativas realizadas pelos INCTs são destacados na sequência.

As etapas da cadeia de inovação onde os institutos atuaram, no período de 2008 a 2014, primeira edição do Programa INCTs, foram sintetizadas e dispostas no Quadro 9. O NANOBIOTECNOLOGIA foi o instituto que indicou contemplar todas as fases da cadeia, ao assinalar as opções apresentadas no relatório de acompanhamento de projeto. Foram marcadas as opções desde a geração de conhecimento com potencial aplicação tecnológica até opção outra indicada como prestação de serviço para a indústria. O DISSE e o NANOCARBONO atuaram em três etapas e o NAMITEC em apenas uma conforme pode ser confirmado no Quadro 9.

Quadro 9 - Cadeia de inovação dos INCTs

\begin{tabular}{|l|c|c|c|c|}
\hline \multirow{2}{*}{ CADEIA DE INOVAÇÃO } & \multicolumn{3}{c|}{ INCT } \\
\cline { 2 - 5 } & DISSE & NAMITEC & NANOBIOTECNOLOGIA & NANOCARBONO \\
\hline $\begin{array}{l}\text { Geração de conhecimentos com } \\
\text { potencial aplicação tecnológica }\end{array}$ & $\times$ & $\times$ & $\times$ & $\times$ \\
\hline Prova de Conceito & $\times$ & $\times$ & $\times$ & $\times$ \\
\hline Projeto Piloto & $\times$ & & $\times$ & $\times$ \\
\hline Escalonamento além da bancada & & & $x$ & \\
\hline $\begin{array}{l}\text { Desenvolvimento final de processo } \\
\text { ou produto }\end{array}$ & & & $x$ & \\
\hline Outra & & & $x^{1}$ & \\
\hline
\end{tabular}

Fonte: Elaboração da autora.

O NANOBIOTECNOLOGIA pontuou como inovações, os projetos desenvolvidos pelo instituto que envolviam a síntese, caracterização e aplicações biológicas (testes em animais de laboratório) de materiais nanoestruturados voltados para a saúde humana, animal e biorremediação. O processo evoluiu e passou por incorporações diversas, dos testes que passaram a ser clínicos, tanto para humanos quanto para animais, como a inclusão de médicos e veterinários.

1 ONANOBIOTECNOLOGIA indicou como outra opção a prestação de serviço para a indústria. 
Esse foi um aparato suficiente para produzir prova de conceito. A necessidade de realizar testes clínicos, fase 1 e fase 2, resultou em associações com hospitais, centros de tratamento e empresas. Compuseram-se parcerias colaborativas em prol da inovação e desenvolvimento de produtos que trouxeram retorno para os vários segmentos da sociedade.

O DISSE pontuou como inovação iniciativas como: a geração de conhecimento para produção de fotodetectores de infravermelho com detectividade otimizada, operação de temperaturas mais elevadas e maior seletividade; atuação na área de células solares com a investigação em nanoestruturas semicondutoras que pudessem baratear esses dispositivos; desenvolvimento de um sistema de detecção de infravermelho para monitorar a presença de $\mathrm{CO}^{2}$, cujo conceito foi demonstrado; desenvolvimento de um equipamento fruto de um projeto piloto, em fase final ; desenvolvimento, dentro do INCT, de um chip de silício para a leitura de sinais de fotodetectores de infravermelho foi desenvolvido e alvo de ampla repercussão na mídia nacional conforme divulgado no CNPq (2013b).

Dentre as ações inovadoras do DISSE identificou-se ainda o desenvolvimento de matrizes biodimensionais e lineares de sensores de infravermelho, utilizando-se sensores do tipo QWIP e fotodiodos de InGaAs. Além dessa, a associação pela primeira vez, de vários grupos de laboratórios brasileiros em trabalho cooperativo em prol do desenvolvimento de fotodetectores de radiação infravermelha para comercialização futura.

O NANOCARBONO sinalizou como frentes de inovação o trabalho desenvolvido em prol da construção de um Centro de Tecnologia de nanotubos, além do escalonamento e produção de compósitos de cimento com nanotubos, em colaboração com a empresa InterCement do grupo Camargo Correa. Também de compósitos com poliuretano e epóxis, em atenção à demanda da Petrobrás, para o desenvolvimento de novos materiais com propriedades superiores para a extração de petróleo do pré-sal.

O NAMITEC indicou como contribuições inovadoras o desenvolvimento de dispositivos, circuitos integrados e redes de sensores sem fio com alto potencial de aplicação tecnológica, além dos trabalhos que incluem prova de conceito desenvolvidos no Instituto.

A discussão e apresentação dos resultados sobre as redes de práticas colaborativas para inovação foi um desmembramento do segundo objetivo da pes- 
quisa. Aproveitou-se a incursão realizada no âmbito das cadeias de inovação e realizou-se um parênteses para inserir a rede da cadeia de inovação construída baseada nas relações indicadas no Quadro 9.

O grafo que representou a rede da cadeia de inovação foi apresentado na Figura 9, e possibilitou a visualização do desenho das conexões diagnosticadas no contexto da rede.

Figura 9 - Grafo da Rede Cadeia de Inovação dos INCTs

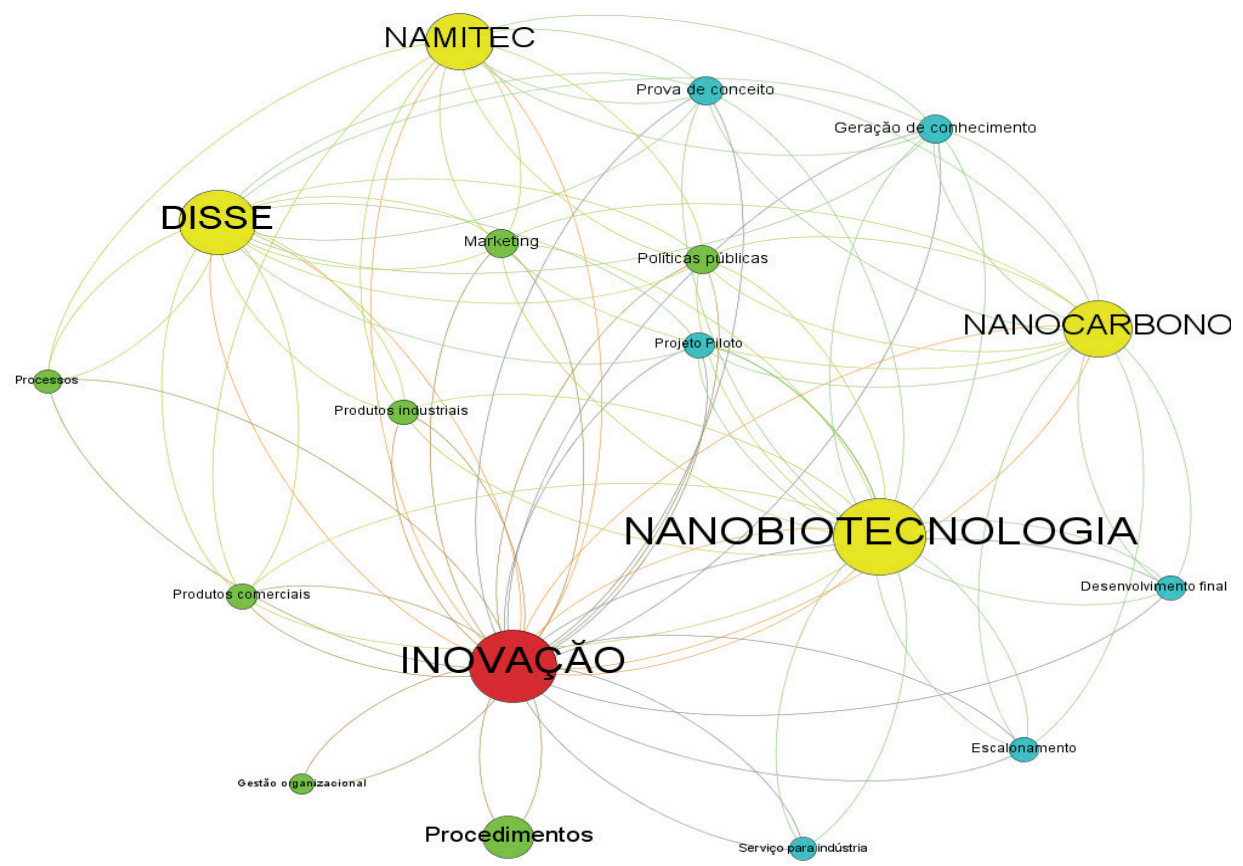

Fonte: Elaboração da autora.

Identificaram-se, no grafo visualizado, 18 nós e 94 arestas. Para visualização, utilizou-se o algoritmo de distribuição do software livre Gephi, Fruchterman-Reingol. A distribuição por cores foi realizada de acordo com os atributos de natureza da rede assim denominados como: cadeia inovadora, tipo, etapa e INCT, os quais foram utilizados apenas para a composição e caracterização da rede porque o foco central foram as interações compreendidas no contexto. 
A caracterização realizada permitiu uma plena visualização dos nós da rede e suas conexões. Em vermelho, identificou-se o nó que representou a inovação, o qual possuía o maior número de arestas interligadas. Sua importância na rede foi identificada de acordo com seu grau médio, um peso de 34, o maior de toda rede e com o maior número de conexões. Em amarelo foram identificados os INCTs: o NANOBIOTECNOLOGIA apareceu em maior destaque, apresentou o maior número de conexões entre os institutos e refletiu as etapas da cadeia de inovação por ele contempladas.

Em azul identificaram-se as etapas da inovação e os tipos, em vermelho. O grafo apresentado permitiu uma visualização distinta da rede e das conexões existentes e não se identificou a criação de clusters volumosos. Infere-se que esta configuração reflita o número de nós dispostos na rede, se um detalhamento maior dos elementos que compõem a cadeia de inovação fosse contemplado, os grupos poderiam evidenciar-se.

Entretanto, como a formação da rede contemplou as informações exclusivas dos relatórios de projeto, este detalhamento não foi possível. Observaram-se apenas as agregações e conexões, de acordo com as iniciativas e práticas que os INCTs contemplaram em seu foco inovador. As métricas gerais da rede foram apresentadas no Quadro 10.

Quadro 10 - Métricas da Rede Cadeia de Inovação

\begin{tabular}{|c|c|}
\hline \multicolumn{2}{|c|}{ REDE CADEIA DE INOVAÇÃO } \\
\hline Métrica & Valores \\
\hline Grau médio & 5,222 \\
\hline Diâmetro da rede & 2 \\
\hline Densidade do grafo & 0,307 \\
\hline Modularidade & 0,086 \\
\hline Componentes conectados & 18 \\
\hline Coeficiente de claustering médio dos nós & 0,401 \\
\hline Cumprimento médio e caminho das arestas & 1,693 \\
\hline
\end{tabular}

Fonte: Elaboração da autora.

As práticas colaborativas podem ser mensuradas de formas distintas. A mais recorrente na comunidade científica realiza-se por meio das colaborações cientí- 
ficas, especialmente com a mensuração das coautorias das produções. No âmbito das práticas realizadas entre as universidades, empresas e institutos de ciência e tecnologia, as interações/integrações também podem ser utilizadas como parâmetro de mensuração, sejam essas no escopo de capacitações, eventos ou construção de artefatos para difusão do conhecimento. Esses resultados puderam ser contabilizados por intermédio dos dados coletados nos relatórios de acompanhamento de projeto.

Os institutos da área de Nanotecnologia registraram um índice elevado de atividades cuja proposta era promover a transferência de conhecimento para a sociedade, em especial ações que contemplavam a divulgação e/ou difusão científica. Elas contemplaram os mais diversos segmentos da sociedade como: o público em geral; profissionais da área; estudantes em todos os níveis de formação e pesquisadores dos INCTs. O Quadro 11 relacionou as atividades contempladas em cada INCT e identificadas nos relatórios.

Quadro 11 - Difusão científica - Práticas

\begin{tabular}{|c|l|}
\hline \multicolumn{2}{|c|}{ PRÁTICAS PARA DIFUSÃo CIENTífICA } \\
\hline INCT & \multicolumn{1}{|c|}{ ATIVIDADES/PRODUTOS } \\
\hline DISSE & $\begin{array}{l}\text { artigo em jornais e revistas, blog, conferência, entrevistas, feiras, fôlders, } \\
\text { Kit: ver o invisível para distribuição em museus e centros de ciência, livreto, } \\
\text { minicursos, notícias na mídia aberta, páginas da Web (site do INCT), painel/ } \\
\text { pôster, palestras, programa de TV, seminário, simpósio, vídeo, visitas a } \\
\text { laboratórios, canal youtube. }\end{array}$ \\
\hline NAMITEC & $\begin{array}{l}\text { boletim informativo, boletim técnico, colóquio, curso de curta duração com } \\
\text { oficina, curso ministrado em eventos, feiras, fôlders, notícias na mídia aberta, } \\
\text { páginas da web (site do INCT), palestras, premiações, programa de rádio, } \\
\text { workshop INCT. }\end{array}$ \\
\hline NANOBIOTECNOLOGIA & $\begin{array}{l}\text { entrevistas, exposição, feiras, jornal (entrevista, notícias), minicursos, palestras, } \\
\text { programa de TV, vídeo "Nanotecnologia: o que é isso?", minilaboratório } \\
\text { portátil para o ensino de química, visita a escolas públicas. }\end{array}$ \\
\hline NANOCARBONO & $\begin{array}{l}\text { artigo em jornais e revistas, colóquio, canal Youtube, curso para pós- } \\
\text { graduação, curso de curta duração, curso de verão, curso online (modalidade } \\
\text { a distância), entrevistas, esculturas, formação de professores em nanociências, } \\
\text { livro, material didático na internet, mesa redonda, minicursos, oficinas, páginas } \\
\text { da web (site do INCT), painel/pôster, palestras, participação em congresso de } \\
\text { ensino ou difusão científica, programa de TV, prospecto, seminário (dobrado), } \\
\text { vídeo, visita a escolas públicas. }\end{array}$ \\
\hline
\end{tabular}

Fonte: Elaboração da autora. 
Identificou-se a preocupação dos institutos em cumprir a missão do Programa INCT, no que se refere à transferência de conhecimento para a sociedade. As atividades implementadas e os produtos distribuídos pelos INCTs foram comprovantes do sucesso dessa frente de atuação em total sintonia com a missão do programa, conforme confirma-se a seguir:

Transferência de conhecimento para a sociedade, utilizando outros instrumentos além da publicação científica. O centro deve ter um programa ambicioso de educação em ciência e difusão de conhecimento, conduzido por seus pesquisadores e pelos bolsistas a ele vinculado, focalizado no fortalecimento do ensino médio e na educação científica da população em geral (PROGRAMA, 2008, p. 5, grifo do autor).

Os INCTs contemplaram distintas modalidades de cursos e atividades voltadas para a difusão científica, além de terem desenvolvido produtos para distribuição com o público alvo. Em termos quantitativos, estes dados representaram o total de 829 atividades/produtos. Os resultados apresentados refletiram a forte atuação do NAMITEC nas atividades voltadas para a difusão científica. Os percentuais apresentados pelos institutos estão destacados no Gráfico 18.

Gráfico 18 - Difusão Científica - Atividades/Produtos

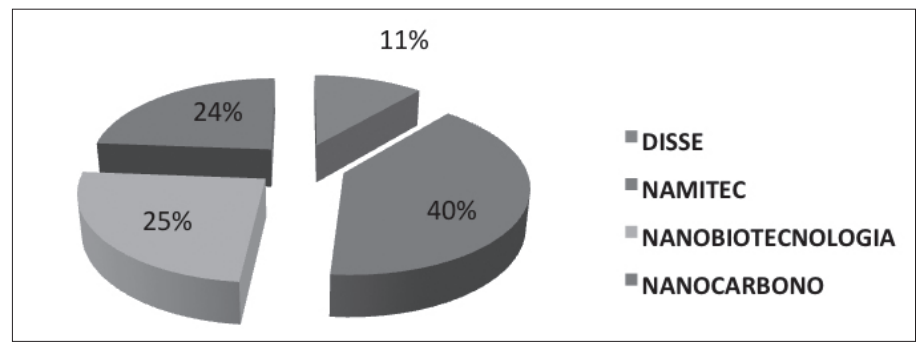

Fonte: Elaboração da autora.

O depoimento de um dos coordenadores do INCT analisado registrou a relevância da atuação do instituto nos cursos realizados. A inserção desses cursos pelo instituto alcançou o Brasil e a América Latina, incidência da internacionalização no âmbito da difusão científica. 
Outra ação do INCT foi fazer cursos a distância. Então essa foi uma iniciativa muito importante também onde nós oferecemos cursos a distância e aberto primeiro ao Brasil, a pessoas leigas e deu muito sucesso e depois até abrimos para a América Latina também e fez muito sucesso.

Dentre as atividades que identificaram as práticas colaborativas para inovação destacaram-se as ações voltadas para a formação de recursos humanos, as quais foram discriminadas como disciplinas ministradas; cursos de pós-graduação stricto senso criados; eventos organizados e parcerias entre os institutos e o estado na área de educação. A Tabela 3 apresentou o resultado a seguir.

Tabela 3 - Ações para formação de recursos humanos

\begin{tabular}{c|c|c|c|c|c}
\hline \multirow{2}{*}{ INCT } & \multicolumn{3}{|c|}{ AÇÕES PARA FORMAÇÃO DE RECURSOS HUMANOS } & \multirow{2}{*}{ Total } \\
\cline { 2 - 5 } & Disciplinas & $\begin{array}{c}\text { Cursos de Pós-Graduação } \\
\text { Stricto Senso }\end{array}$ & Eventos & $\begin{array}{c}\text { Parcerias / Estado } \\
\text {-Educação }\end{array}$ & 29 \\
\hline DISSE & 18 & 2 & 9 & 0 & 37 \\
\hline NAMITEC & 0 & 3 & 4 & 3 & 21 \\
\hline NANOBIOTECNOLOGIA & 14 & 1 & 10 & 1 & 23 \\
\hline Total & 12 & 0 & 54 & 6 & 110 \\
\hline
\end{tabular}

Fonte: Elaboração da autora.

O NAMITEC confirmou sua acentuada atuação nas ações referentes à formação de recursos humanos, um ganho sintonizado com seus objetivos. Levando-se em consideração, a composição da rede de pesquisadores que atuam no instituto e a reunião de fatores que influenciaram o resultado obtido, esse era esperado. Esse instituto apresentou o maior número de pesquisadores vinculados à sua rede de colaboração. A sede estar situada na região sudeste do país caracterizou posição privilegiada, levando-se em consideração as oportunidades e fontes para financiamentos existentes, além de possuir grande número de instituições associadas. Esses elementos favoráveis para a realização de articulações e parcerias se refletiram nos quantitativos computados e o deixou quase sempre em vantagem em relação aos outros INCTs investigados.

As ações para a formação de recursos humanos ressaltaram a atuação do NAMITEC. Entretanto, a prática efetiva foi realizada por todos os outros INCTs 
analisados, um resultado pontuado na indicação da prática colaborativa mais recorrente e também quantificado e apresentado ao longo desta seção.

Destacaram-se os eventos organizados pelos institutos das ações acima contempladas e realizada a quantificação no âmbito regional, nacional e internacional. Os eventos organizados pelos INCTs foram identificados também nos resultados referentes à produção científica. Essa produção foi significativa e apresentou, além de artigos de periódicos, trabalhos publicados em anais nos diversos eventos, dentre eles os que foram organizados pelos institutos na área de Nanotecnologia. A Tabela 4, resgatou o quantitativo dos eventos organizados.

Tabela 4 - Eventos organizados pelos INCTs

\begin{tabular}{l|c|c|c|c}
\hline \multirow{2}{*}{ INCT } & \multicolumn{3}{|c|}{ EVENTOS ORGANIZADOS } & \multirow{2}{*}{ TOTAL } \\
\cline { 2 - 5 } & REGIONAL & NACIONAL & INTERNACIONAL & 9 \\
\hline DISSE & 3 & 5 & 1 & 31 \\
\hline NAMITEC & 12 & 4 & 15 & 6 \\
\hline NANOBIOTECNOLOGIA & 2 & 0 & 4 & 10 \\
\hline NANOCARBONO & 0 & 7 & 3 & 56 \\
\hline TOTAL & 17 & 16 & 23 & \multirow{2}{*}{} \\
\hline
\end{tabular}

Fonte: Elaboração da autora.

O conjunto de práticas colaborativas identificadas indicou alguns indícios da interferência dessas ações na produção científica dos pesquisadores dos INCTs. As interações/integrações, as inovações e os eventos realizados favoreceram a produção científica e resultou em novos insumos coroando o processo. O depoimento de um dos coordenadores dos INCTs ilustra a relevância dos eventos presenciais realizados e a efetiva participação dos pesquisadores e alunos da área.

[...] na interação a coisa mais importante são as reuniões presenciais, são os encontros anuais. Nesses encontros anuais todo mundo se conhece porque você tem um ambiente, têm as reuniões, as sessões de pôsteres, você tem todos os estudantes, as pessoas tem a oportunidade de se conhecer pessoalmente, trocar ideias, um vê o pôster..., um aluno vê o pôster do outro. Então em minha opinião, em termos de colaboração dentro do âmbito do INCT eu senti que foi mais efetivo o encontro presencial, nos encontros anuais surgiram muitas colaborações, mais do que nessas ferramentas, nesses sites. 
Quanto mais práticas colaborativas ocorrerem e eventos forem organizados pelos institutos, maiores as possibilidades de produção e apresentação de resultados por seus pesquisadores. No que se refere à produção científica, os resultados apontam positivamente.

Os institutos estavam tão imbuídos dos seus propósitos e em consonância com as recomendações estabelecidas pelo Programa INCTs que recomendavam ações frequentes para a difusão científica. A programação de novas ações para apresentar os resultados de suas práticas científicas expressa essa convicção. Este planejamento foi alvo do escrutínio da autora, que os congregou no Quadro 12.

Quadro 12 - Difusão científica - Planejamento de ações

\begin{tabular}{|c|c|c|c|c|c|}
\hline \multirow{2}{*}{$\begin{array}{l}\text { DIFUSÃO CIENTÍFICA - } \\
\text { PLANEJAMENTO DE AÇÕES }\end{array}$} & \multicolumn{4}{|c|}{ INCT } & \multirow{2}{*}{ Total } \\
\hline & DISSE & NAMITEC & NANOBIOTECNOLOGIA & NANOCARBONO & \\
\hline Artigos de divulgação científica & 1 & & & & 1 \\
\hline Boletim Informativo & & 6 & & & 6 \\
\hline Blog & 1 & & & & 1 \\
\hline Colóquio & & 2 & & & 2 \\
\hline Congresso & & 3 & & & 3 \\
\hline Cursos de curta duração & & 3 & & & 3 \\
\hline Disciplinas de pós-graduação & & & 1 & & \\
\hline Encontro internacional & & & 1 & & 1 \\
\hline Elaboração de site & & 1 & & & 1 \\
\hline Kit: ver o invisível & 1 & & & & 1 \\
\hline Livro & & & 1 & & 1 \\
\hline Mini Laboratório Portátil & & & 1 & & 1 \\
\hline Museu virtual de nanotecnologia & 1 & & & & 1 \\
\hline Oficinas & & 1 & & & 1 \\
\hline Palestra & & 1 & 3 & & 4 \\
\hline Participação em feiras & 1 & & & & 1 \\
\hline Programa de rádio & & & & 1 & 1 \\
\hline Programa de TV & & & & 1 & 1 \\
\hline Vídeo & 1 & & 2 & 1 & 4 \\
\hline Workshop INCT & & 1 & & & 1 \\
\hline TOTAL & 6 & 18 & 9 & 3 & 36 \\
\hline
\end{tabular}

Fonte: Elaboração da autora. 
Esse planejamento ilustrou o desejo de fortalecer as ações realizadas até então e abrir novas frentes para a difusão da Ciência, e como consequência promover o reconhecimento e também a divulgação da área de Nanotecnologia, tão importante para a sociedade em diversos aspectos e frentes de aplicações, mas ainda pouco conhecida pela maioria da população.

Nanotecnologia, é uma área do conhecimento que causa muita curiosidade e expectativa, especialmente para a parcela da sociedade na qual o tema é pouco difundido. Esse mundo desconhecido e cheio de mistérios pouco a pouco vem sendo desmistificado. Ações como as que foram contempladas pelos INCTs contribuem significativamente para diminuir o espaço entre a sociedade e a Nanotecnologia. A preocupação desses institutos em reverter a situação presente é evidente e está registrada no planejamento realizado e na intenção de levar para a população melhor compreensão sobre a área.

Os resultados obtidos nos INCTs referentes à formação de recursos humanos não se encerraram. Destacaram-se ainda os achados concernentes à formação em segmentos da academia os quais contemplam desde a base até os mais altos degraus de titulação. A apresentação desses resultados evidenciou a correlação entre as práticas colaborativas desenvolvidas e os objetivos do Programa INCTs, no que se refere à formação de pesquisadores contemplados na iniciação científica, mestrado, doutorado e estágio pós-doutoral. A missão dos INCTs é clara quando destaca sua pretensão no item referente à formação de recursos humanos, conforme se destaca:

Formação de Recursos Humanos. O Instituto deve promover a formação de pessoal qualificado, por meio de cursos de pós-graduação e por meio de envolvimento de estudantes de graduação. Para aqueles IN's voltados a aplicações, tecnologia e relações com empresas, espera-se, além da formação de cientistas acadêmicos de nível internacional, que haja treinamento em ambiente empresarial, cursos de curta e longa duração, treinamento de técnicos especializados, entre outros. Para IN's voltados à ciência básica e fundamental espera-se a formação de cientistas com inserção internacional e com impacto na criação de ciência e em sua difusão (PROGRAMA..., 2008, p. 5, grifo do autor). 
A quantificação do resultado referente à formação de recursos humanos foi positiva. Foram formados 1.017 alunos nos diversos níveis de atuação acadêmica. Os INCTs que apresentaram os maiores percentuais de formação em recursos humanos foram o NAMITEC (38\%) e o NANOBIOTECNOLOGIA (37\%), resultados sintonizados com os dados apresentado nos parágrafos anteriores. O Gráfico 19 detalhou a quantificação obtida pelos institutos.

Gráfico 19 - Formação de recursos humanos

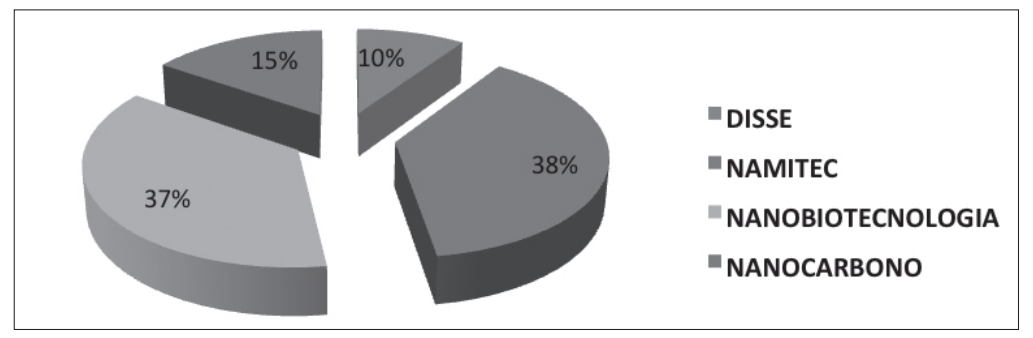

Fonte: Elaboração da autora.

Os níveis contemplados foram: iniciação científica, mestrado, doutorado e estágio pós-doutoral. A formação da base científica foi a maior preocupação do NANOBIOTECNOLOGIA e esse instituto registrou o total de 191 alunos de iniciação científica em suas atividades. Contudo, o NAMITEC, instituto com ações diversas nessa frente de atuação, não registrou nenhum alunos neste nível de formação. O DISSE e o NANOCARBONO, com 50 e 28 alunos respectivamente, registraram discreta atuação neste nível. Entretanto, a formação no doutorado foi a que contemplou o maior número de registros, o total de 395 alunos, dados satisfatórios e indicativos do sucesso na atuação dos INCTs, ressalvadas as proporções e dificuldades peculiares de cada instituto. O Gráfico 20 ressaltou as informações pontuadas. 
Gráfico 20 - Níveis de formação dos recursos humanos

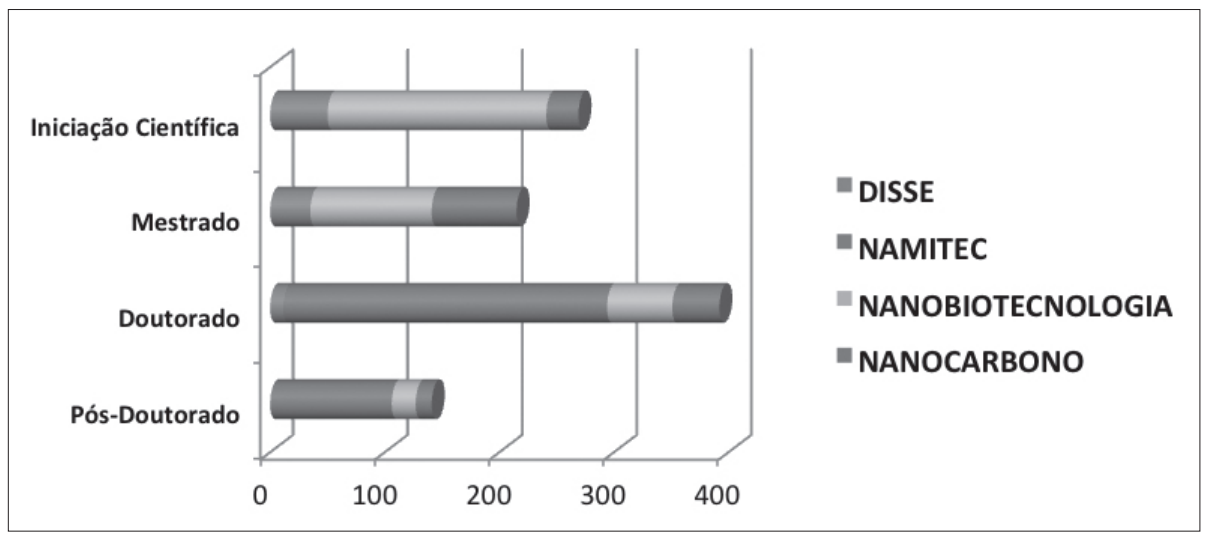

Fonte: Elaboração da autora.

Os resultados da formação de recursos humanos foram insumos representados pela produção científica e estavam alinhados com mais uma missão do Programa INCT no que se refere ao desenvolvimento de pesquisas, conforme se destacou a seguir:

Pesquisa. Promoção de pesquisa de vanguarda e elevada qualidade, de padrão competitivo internacionalmente na área de conhecimento. O centro deve ser estruturado e funcionar como uma referência de excelência nacional na sua área de atuação, de modo a contribuir efetivamente para o desenvolvimento nacional segundo as metas definidas no Plano Nacional de Ciência, Tecnologia e Inovação para o Desenvolvimento Nacional (PROGRAMA..., 2008, p. 5, grifo do autor).

O extrato da produção científica analisado evidenciou a sintonia existente entre a formação e o produto, uma evidência dos esforços desprendidos pelos INCTs para cumprir o que foi solicitado no edital do Programa INCTs, como destacado. O Gráfico 21 permitiu a visualização dos dados obtidos. 
Gráfico 21 - Formação de recursos humanos - Produção científica

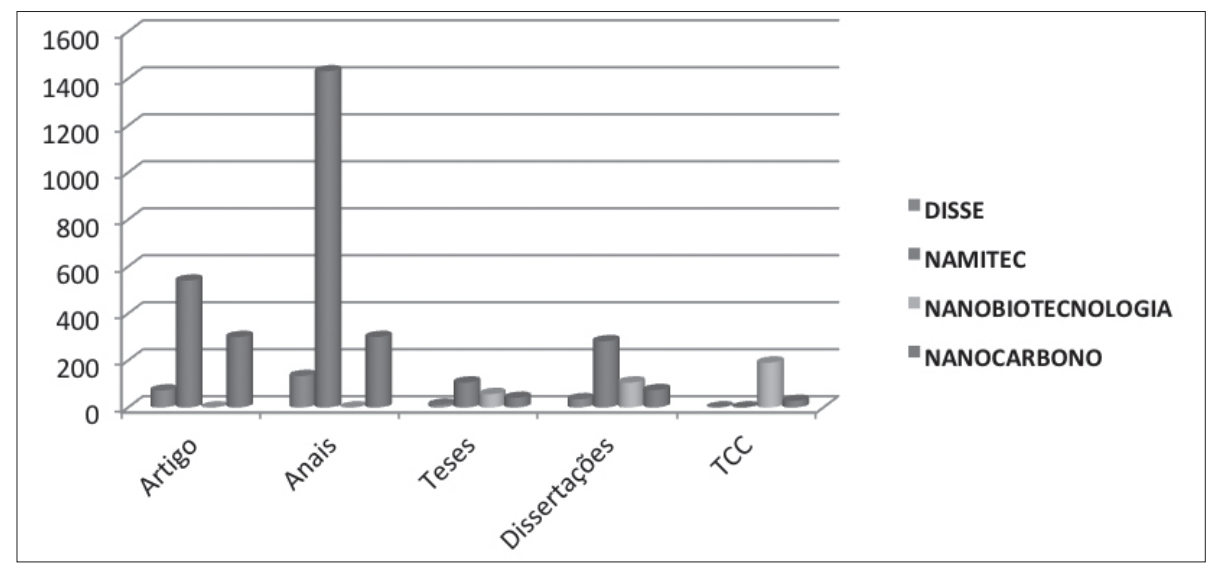

Fonte: Elaboração da autora.

O Gráfico 21, sinalizou para um resultado obtido com base nas informações retiradas dos relatórios de acompanhamento de projeto dos coordenadores dos INCTs investigados. Desse modo, faz-se necessário registrar que o NANOBIOTECNOLOGIA não indicou a produção científica em artigos e anais, no relatório existia a informação de que este dado seria enviado posteriormente. O NANOCARBONO forneceu a informação, de modo impreciso para os anais. Estava indicado "mais de 300", utilizou-se como base para a quantificação o número 300.

\section{Redes de práticas colaborativas para inovação}

Os resultados provenientes dos dados coletados nos relatórios de acompanhamento de projeto dos INCTs da área de Nanotecnologia forneceram os subsídios necessários para a identificação das redes colaborativas existentes nos institutos. A incursão que foi realizada nos relatórios permitiu a identificação não apenas das redes de práticas colaborativas. Conforme sinalizou Latour (2012) as diversas formações de grupos e alistamentos em grupos contraditórios puderam ser percebidas.

Algumas das redes identificadas foram: a rede de colaboração dos pesquisadores dos INCTs da área de Nanotecnologia, no âmbito da produção científica; a rede das práticas colaborativas, no âmbito das interações entre os INCTs e os atores que a compuseram; a rede dos INCTs e artefatos pertinentes à infraestrutura e-Science; a rede da cadeia de inovação; a rede dos INCTs e políticas públicas que 
sustentaram o Programa e seu entorno; a rede das universidades; das instituições; das organizações; dos agentes de fomento; das empresas; dos laboratórios; dos hospitais, e muitas outras pontuadas no conglomerado investigado.

As exigências encerradas no segundo objetivo específico da pesquisa. A identificação das práticas e redes colaborativas efetivas dos pesquisadores foram contempladas. Os resultados obtidos nesta etapa da pesquisa foram satisfatórios. Uma seleção das redes identificadas foi realizada para manter o foco no objetivo proposto. Contemplou-se desse modo, na análise realizada, a rede de práticas colaborativas para inovação dos INCTs da área de Nanotecnologia.

A Análise de Redes Sociais, um dos métodos utilizados nesta pesquisa, foi o parâmetro para definir e interpretar a rede identificada e a representação por grafos permitiu a visualização dos laços característicos da rede. As interações entre os atores/actantes identificados, ou na linguagem da ARS, dos nós conectados, as posições assumidas e os elos existentes foram pontos contemplados com as métricas pertinentes aplicadas.

As métricas utilizadas para obtenção de uma visão geral da rede foram baseadas nos parâmetros fornecidos pelo software livre Gephi, versão beta 0.8.02, descritas por (MARQUEZ, 2013) por ele denominadas como estatísticas:

- grau médio para indicar o peso dos nós de acordo com a quantidade de suas conexões na entrada e saída;

- diâmetro da rede calculando-se a distância média do grafo entre os pares de nós. As medidas de centralidade de intermediação, proximidade e excentricidade foram contempladas;

- densidade do grafo para identificar quanto faltava para a rede estar completa;

- modularidade para definir os clusters de acordo com a força de suas conexões e detectar as comunidades existentes.

A visão geral dos nós pode ser obtida com os valores do coeficiente de clustering médio e o das arestas com o cumprimento médio de caminho.

A rede das práticas colaborativas para inovação dos INCTs da área de Nanotecnologia foi identificada e apresentou 248 nós e 1.196 arestas. Os atributos utilizados na caracterização da rede contemplaram: estrutura; dimensão jurídica; alcance geográfico, tipo de interação, e o ambiente onde ocorreram as práticas. 
Para uma visualização o mais limpa possível, utilizou-se o algoritmo de distribuição do software livre Gephi, Fruchterman-Reingol. As cores características dos atores/actantes apresentados foram definidas tomando-se por base a estrutura identificada na rede. As universidades foram representadas pela cor vermelha; as empresas pelo azul-marinho; os laboratórios pelo verde claro; as instituições pelo azul; os INCTs pelo amarelo; as políticas pelo laranja; as organizações pelo vinho; os agentes de fomento pelo lilás; e os hospitais pelo verde escuro. A Figura 10 apresentou a rede identificada.

Figura 10 - Grafo da Rede de Práticas Colaborativas para Inovação

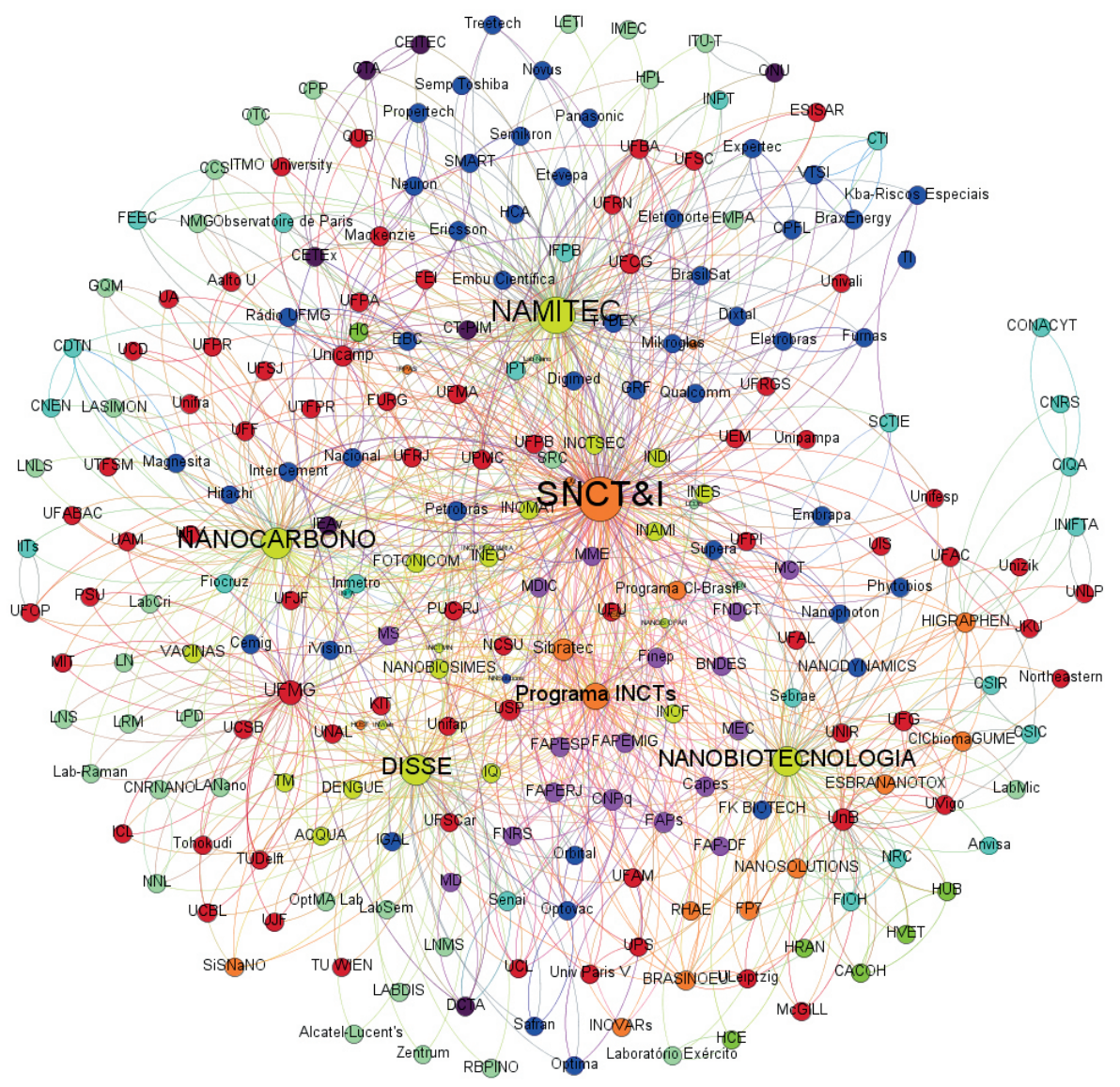

Fonte: Elaboração da autora. 
Contemplar o invisível e transformar suas propriedades em aplicações úteis para a sociedade foi uma das ambições identificadas na área de Nanotecnologia. Tornar o invisível visível para poder ser analisado foi o que propuseram Urs e Sharma (2010) com a utilização da análise das redes sociais. Uma das contribuições da pesquisa realizada foi a combinação que permitiu a visualização das interações e práticas colaborativas ocorridas na área de Nanotecnologia com o instrumental da ARS. Um desafio realizado de modo satisfatório.

O resultado das métricas da rede de práticas colaborativas para inovação foi apresentado no Quadro 13.

Quadro 13 - Métricas da Rede de Práticas Colaborativas para Inovação

\begin{tabular}{|l|c|}
\hline \multicolumn{2}{|c|}{ REDE DE PRÁTICAS COLABORATIVAS PARA INOVAÇÃO } \\
\hline \multicolumn{1}{|c|}{ MÉTRICA } & VALORES \\
\hline Grau médio & 4,81 \\
\hline Grau ponderado médio & 4,83 \\
\hline Densidade do grafo & 0,19 \\
\hline Modularidade & 0,44 \\
\hline Componentes conectados & 4 \\
\hline Coeficiente de claustering médio dos nós & 0,71 \\
\hline Cumprimento médio e caminho das arestas & 2,6 \\
\hline
\end{tabular}

Fonte: Elaboração da autora.

Os atributos de uma rede não são os seus principais elementos nem o principal foco de atenção. As conexões e interações entre os atores que a compõem são o foco central, conforme destacaram Wasserman e Faus (1994, p. 8, tradução nossa) em sua assertiva:

$\mathrm{Na}$ análise de redes sociais os atributos observados a partir dos atores sociais (tais como raça ou etnia das pessoas, ou o tamanho ou produtividade dos organismos coletivos, tais como empresas ou estados-nações) são compreendidos em termos de padrões ou estruturas de laços entre as unidades. As ligações relacionais entre atores são os focos primários e os atributos secundários. 
Contudo, o objetivo específico em atenção nesta seção focou a identificação das práticas e redes colaborativas para inovação, o que requereu atenção redobrada aos atributos para atender a esse requisito; apesar de serem considerados como elementos secundários, em uma análise de redes sociais, nesta pesquisa não poderiam ser negligenciados.

Uma síntese da identificação dos atores/actantes e atributos contemplados na rede foi apresentada no Quadro 14.

Quadro 14 - Atores/Actantes e atributos da rede

\begin{tabular}{|c|c|c|c|c|c|}
\hline \multirow[b]{2}{*}{ Ator/Actante } & \multicolumn{5}{|c|}{ Atributos } \\
\hline & Estrutura & $\begin{array}{l}\text { Dimensão } \\
\text { Jurídica }\end{array}$ & $\begin{array}{c}\text { Alcance } \\
\text { Geográfico }\end{array}$ & Prática colaborativa & Ambiente \\
\hline Aalto $U$ & Universidade & pública & estrangeiro & Formação de Recursos Humanos & externo \\
\hline ACQUA & INCT & pública & nacional & Colaboração Científica & interno \\
\hline Alcatel-Lucent's & Laboratório & pública & estrangeiro & Compartilhamento de Recursos & externo \\
\hline Anvisa & Instituição & pública & nacional & Colaboração Científica & externo \\
\hline BNDES & Agente de fomento & pública & nacional & Fomento & externo \\
\hline Brasilsat & Empresa & pública & nacional & Atividades de $P \& D$ & externo \\
\hline BRASINOEU & Políticas & pública & estrangeiro & Fomento & externo \\
\hline BraxEnergy & Empresa & privada & nacional & Atividades de $P \& D$ & externo \\
\hline $\mathrm{CACOH}$ & Hospital & pública & nacional & Colaboração Científica & externo \\
\hline Capes & Agente de fomento & pública & nacional & Fomento & externo \\
\hline $\operatorname{cCS}$ & Laboratório & pública & nacional & Compartilhamento de Recursos & externo \\
\hline CDTN & Instituição & pública & nacional & Colaboração Científica & externo \\
\hline CEITEC & Organização & pública/social & nacional & Formação de Recursos Humanos & externo \\
\hline Cemig & Empresa & mista & nacional & Atividades de $P \& D$ & externo \\
\hline CETEX & Organização & militar & nacional & Colaboração Científica & externo \\
\hline ClCbiomaGUNE & Políticas & pública & estrangeiro & Colaboração Científica & externo \\
\hline CIQA & Instituição & pública & estrangeiro & Colaboração Científica & externo \\
\hline CNEN & Instituição & pública & nacional & Colaboração Científica & externo \\
\hline CNPq & Agente de fomento & pública & nacional & Fomento & externo \\
\hline CNRNANO & Instituição & pública & estrangeiro & Compartilhamento de Recursos & externo \\
\hline
\end{tabular}




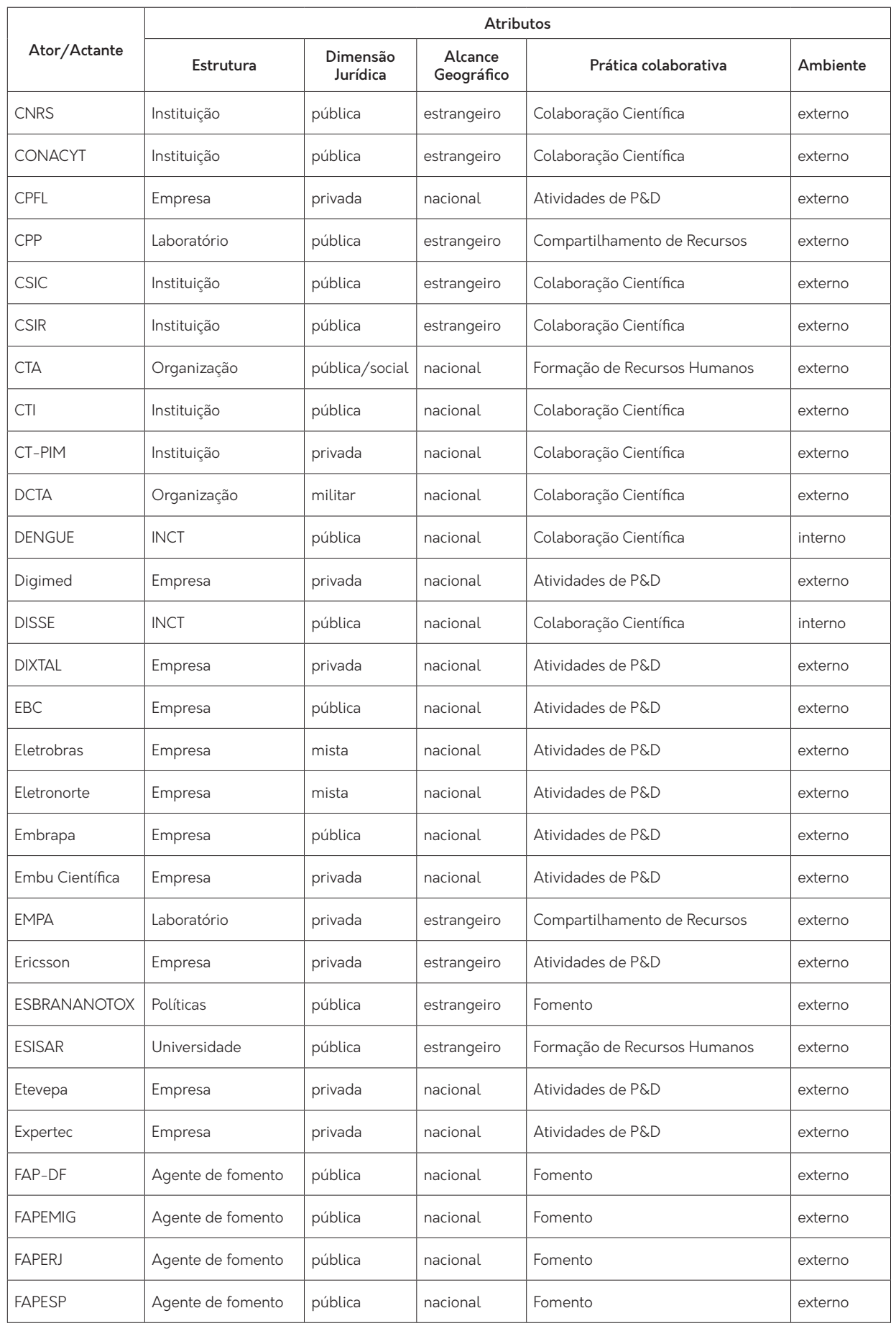




\begin{tabular}{|c|c|c|c|c|c|}
\hline \multirow[b]{2}{*}{ Ator/Actante } & \multicolumn{5}{|c|}{ Atributos } \\
\hline & Estrutura & $\begin{array}{c}\text { Dimensão } \\
\text { Jurídica }\end{array}$ & $\begin{array}{l}\text { Alcance } \\
\text { Geográfico }\end{array}$ & Prática colaborativa & Ambiente \\
\hline FAPs & Agente de fomento & pública & nacional & Fomento & externo \\
\hline FEEC & Instituição & pública & nacional & Formação de Recursos Humanos & externo \\
\hline FEl & Universidade & privada & nacional & Formação de Recursos Humanos & externo \\
\hline Finep & Agente de fomento & pública & nacional & Fomento & externo \\
\hline Fiocruz & Instituição & pública & nacional & Formação de Recursos Humanos & externo \\
\hline $\mathrm{FIOH}$ & Instituição & pública & estrangeiro & Formação de Recursos Humanos & externo \\
\hline FK BIOTECH & Empresa & privada & nacional & Atividades de $P \& D$ & externo \\
\hline FNDCT & Agente de fomento & pública & nacional & Fomento & externo \\
\hline FNRS & Agente de fomento & pública & estrangeiro & Fomento & externo \\
\hline FOTONICOM & INCT & pública & nacional & Colaboração Científica & interno \\
\hline FP7 & Políticas & pública & estrangeiro & Fomento & externo \\
\hline FURG & Universidade & pública & nacional & Formação de Recursos Humanos & externo \\
\hline Furnas & Empresa & mista & nacional & Atividades de $P \& D$ & externo \\
\hline GQM & Laboratório & pública & nacional & Compartilhamento de Recursos & externo \\
\hline GRF & Empresa & privada & nacional & Atividades de $P \& D$ & externo \\
\hline $\mathrm{HC}$ & Hospital & pública & nacional & Colaboração Científica & externo \\
\hline HCA & Empresa & privada & nacional & Atividades de $P \& D$ & externo \\
\hline HCE & Hospital & pública & nacional & Colaboração Científica & externo \\
\hline HIGRAPHEN & Políticas & pública & estrangeiro & Fomento & externo \\
\hline Hitachi & Empresa & pública & estrangeiro & Atividades de $P \& D$ & externo \\
\hline HPL & Laboratório & privada & estrangeiro & Compartilhamento de Recursos & externo \\
\hline HRAN & Hospital & pública & nacional & Colaboração Científica & externo \\
\hline HUB & Hospital & pública & nacional & Colaboração Científica & externo \\
\hline HUST & Políticas & pública & estrangeiro & Fomento & externo \\
\hline HVET & Hospital & pública & nacional & Colaboração Científica & externo \\
\hline ICL & Universidade & pública & estrangeiro & Formação de Recursos Humanos & externo \\
\hline IEAv & Organização & militar & nacional & Formação de Recursos Humanos & externo \\
\hline
\end{tabular}

Fonte: Elaboração da autora. 
$\mathrm{Na}$ rede de práticas colaborativas para inovação, os atributos constituíram um elemento a mais e foram imprescindíveis durante o rastreamento das conexões ocorridas, identificação necessária para responder à questão acerca do estabelecimento e solidificação das redes de colaboração nos INCTs.

A estrutura da rede de práticas colaborativas para inovação foi o primeiro atributo a ser pontuado nos resultados apresentados e permitiu identificar sob que alicerces estavam agregados os atores/actantes, nas relações colaborativas rastreadas e qual o papel por eles incorporado, a dimensão das interações e as parcerias realizadas. O Gráfico 22, permitiu a plena visualização dos resultados obtidos.

Gráfico 22 - Estrutura da Rede de Práticas Colaborativas para Inovação

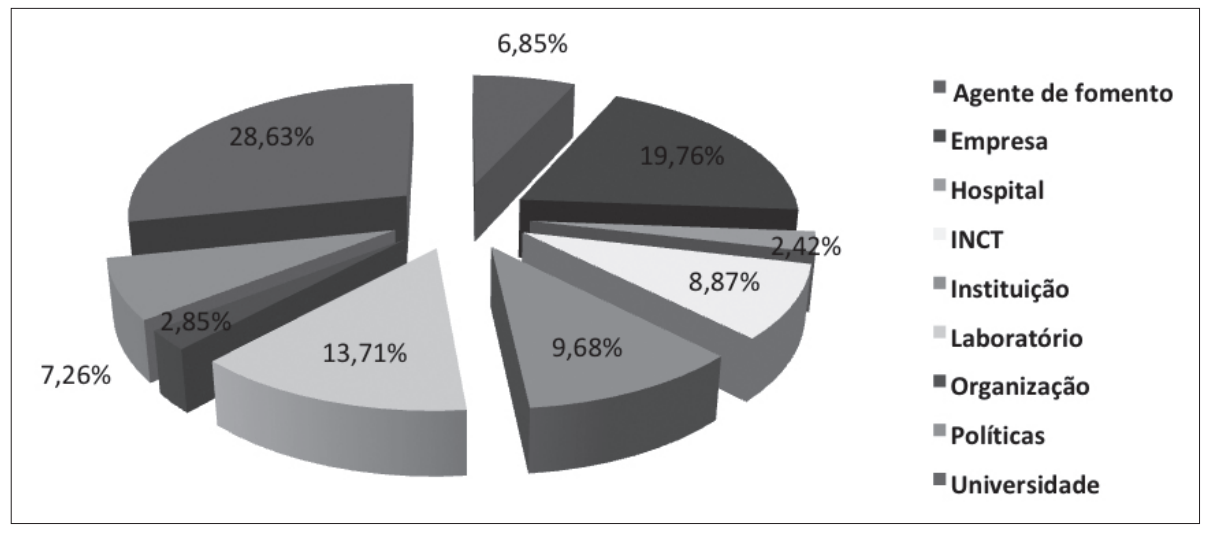

Fonte: Elaboração da autora.

O modelo do "Triângulo de Sabáto" considerou o governo, a universidade e a empresa como atores chaves que interagem para gerar inovação (ESCALATE LUDEÑA, 2008). Dentre os componentes da rede identificada, a universidade foi o que melhor se fez representar $(28,63 \%)$, percentual que a indicou como ambiente acadêmico tradicional e favorável para as práticas colaborativas realizadas e iniciativas para a inovação.

A seguir, as empresas (19,76\%) e o governo (14,11\%), representado pelos agentes de fomento e políticas. Os atores não considerados no modelo do "Triângulo de Sabáto” obtiveram representatividade significativa. Dentre esses, desta- 
caram-se os laboratórios (13,71\%), as instituições $(9,68 \%)$ e os INCTs $(8,87 \%)$; as organizações $(2,82 \%)$ e os hospitais $(2,42 \%)$.

A depender do papel incorporado pelos atributos identificou-se a atuação dos atores/actantes, como intermediários ou mediadores. Os intermediários e mediadores, resgatados do vocabulário de Latour (2012), determinaram a natureza íntima dos atores/actantes identificados na rede. Os intermediários transportaram significado e força sem transformar. Dos atores/actantes que incorporaram este papel, o resultado de suas ações e funções foi previsível.

Dos atores/actantes que incorporavam o papel de mediadores, ao contrário, os resultados eram imprevisíveis e eles puderam transformar traduzir, distorcer e modificar o significado ou os elementos que supostamente veiculavam e faziam parte de suas interações. O Quadro 15 sinalizou para a indicação atribuída aos atores/actantes, enquanto intermediários ou mediadores na rede apresentada. A rede de práticas colaborativas para inovação, possui um número reduzido de mediadores, mais com um forte poder de transformação, o qual caracterizou-se em um caldeirão de conexões que fervilhavam e modificaram os resultados obtidos nas interações realizadas.

Quadro 15 - Atores mediadores e intermediários da rede

\begin{tabular}{|l|c|}
\hline \multicolumn{1}{|c|}{ ESTRUTURA } & PAPEL \\
\hline Universidade & intermediário \\
\hline Políticas & mediadores \\
\hline Organização & intermediário \\
\hline Laboratório & intermediário \\
\hline Instituição & intermediários \\
\hline INCT & mediadores \\
\hline Hospital & intermediário \\
\hline Empresa & intermediários \\
\hline Agente de fomento & mediadores \\
\hline
\end{tabular}

Fonte: Elaboração da autora.

A dimensão jurídica característica dos atores/actantes foi o atributo identificado em seguida. A inserção dos atores/actantes na esfera pública (73\%) foi coe- 
rente com o perfil suposto para uma rede na qual ocorrem práticas colaborativas que necessitam de fomento, suporte e infraestrutura; os órgãos governamentais são os principais responsáveis por essa atribuição. Os atores/actantes inseridos na esfera privada (22\%) figuraram em percentual significativo no contexto do segmento representado, o qual necessita de estímulos e incentivos para se fazer presente, entretanto, ainda com um espaço muito vasto para inserção.

Identificaram-se ainda atores/actantes inseridos nas dimensões mista e mili$\operatorname{tar}(4 \%)$ e na pública com um cunho social (1\%). O Gráfico 23 permitiu a visualização da representação pontuada.

Gráfico 23 - Dimensão jurídica da rede

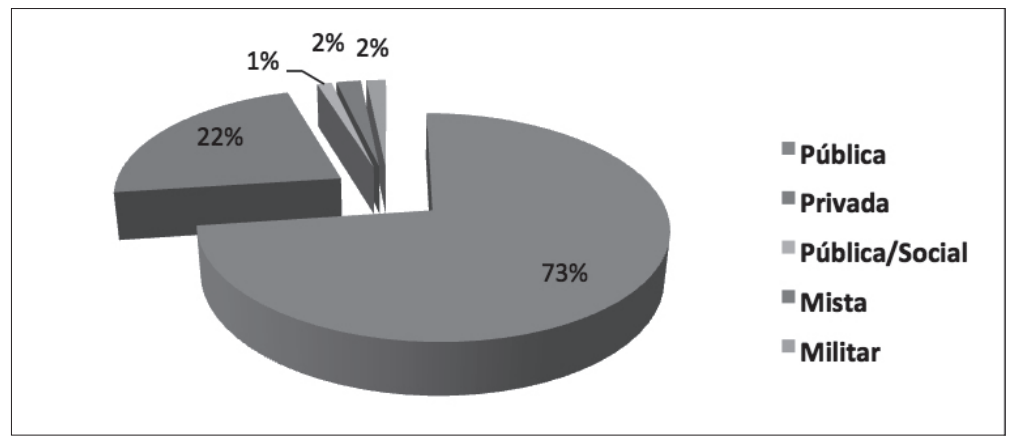

Fonte: Elaboração da autora.

Em termos espaciais, a maioria dos atores/actantes da rede (70\%) ainda estão restritos ao âmbito nacional. $\mathrm{O}$ alcance geográfico coberto pelos atores/actantes da rede sinalizou para a necessidade de maior inserção na esfera estrangeira (30\%). Tomando-se por base o amplo desenvolvimento da área da Nanotecnologia no mundo, fazem-se necessários investimentos direcionados a maior inserção internacional. Essa é uma das metas do Programa INCT e, apesar dos esforços empreendidos, são prementes novas parcerias com vistas a implementar esse aspecto. O Gráfico 24 ilustrou os percentuais obtidos por cada esfera geográfica. 
Gráfico 24 - Alcance geográfico da rede

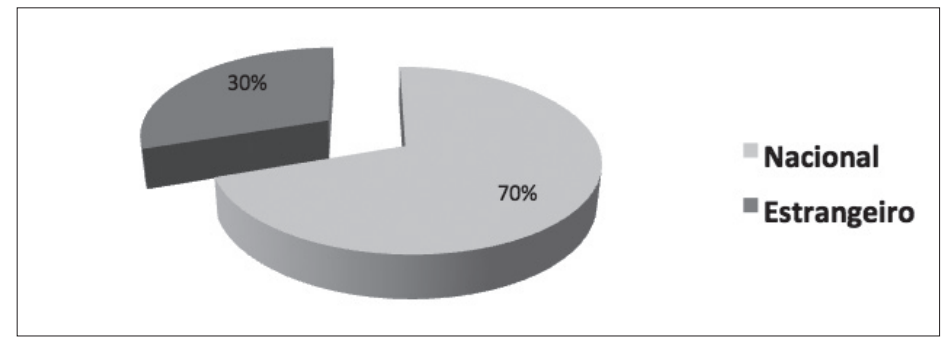

Fonte: Elaboração da autora.

Durante o rastreamento das conexões segmentadas foi possível identificar o tipo predominante das práticas realizadas pelos atores/actantes da rede. A característica da interação realizada foi um dos resultados obtidos, a qual justificou a atenção desprendida na análise dos atributos da rede. Neste momento, as atividades apresentadas foram agregadas de acordo com a natureza.

Faz-se oportuno registrar, que apesar da quantificação do resultado sinalizar para apenas uma indicação do tipo de prática contemplada foi constatada a ocorrência ao mesmo tempo, da realização de vários tipos, pelos atores/actantes. Este comportamento foi identificado também nos resultados das práticas colaborativas nos INCTs analisados. Para efetuar uma quantificação coerente levou-se em consideração os atores envolvidos na interação e as atividades predominantes do grupo em análise. Por exemplo, a prática da colaboração científica que permeou as diversas interações foi contabilizada, apenas nas estruturas que efetivamente the era peculiar e ocorria com uma maior regularidade. Nos laboratórios a predominância foi pelo compartilhamento de recursos, contudo a colaboração científica e a formação de recursos humanos também ocorriam. Desse modo, privilegiou-se a indicação na atividade de compartilhamento por ser mais frequente.

Observou-se harmonia entre os resultados obtidos na rede e nos relatórios analisados, no que se refere às efetivas práticas colaborativas realizadas. A colaboração científica, com um percentual de 22,18\% manteve sua frequência de realização entre atores/actantes da rede. Conforme se pode confirmar no Gráfico 25 . 
Gráfico 25 - Práticas colaborativas na rede

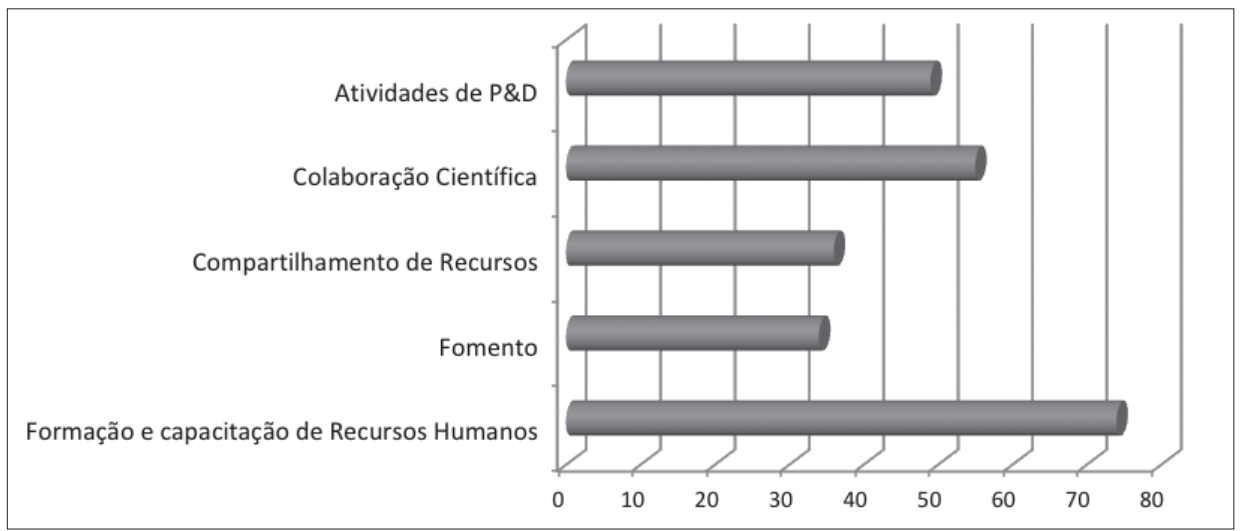

Fonte: Elaboração da autora.

As atividades de $\mathrm{P} \& \mathrm{D}(19,75 \%)$ sinalizaram a crescente presença das empresas no âmbito das parcerias colaborativas implementadas e o compartilhamento de recursos (14,51\%) indicaram o aproveitamento de equipamentos tão característico das práticas colaborativas. A interação para a formação e capacitação de recursos humanos registrada na rede $(29,84 \%)$ corroborou os índices contemplados na análise das práticas colaborativas pertinentes aos INCTs e a colaboração científica confirmou a presença dessa atividade de modo ativo nas interações realizadas.

$\mathrm{O}$ ambiente em que ocorreram as práticas colaborativas na rede foi efetivamente externo (91\%) em detrimento do ambiente interno (9\%). O Gráfico 26 ilustrou o resultado obtido.

Gráfico 26 - Práticas colaborativas - Ambiente

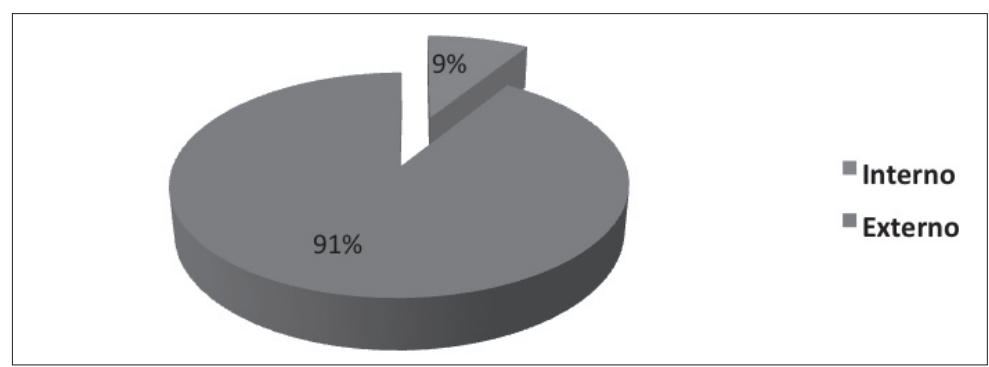

Fonte: Elaboração da autora. 
As práticas colaborativas internas foram caracterizadas pelas interações realizadas entre os INCTs. A interação entre os institutos, específicos da área de Nanotecnologia foi pequena levando-se em conta as práticas realizadas com os atores/actantes do ambiente externo identificadas nas acentuadas conexões. As interações com o ambiente externo são muito bem-vindas pois expande o alcance da rede. Contudo, os INCTs da área de Nanotecnologia analisados precisam ampliar as colaborações no âmbito interno, esse comportamento solidificará as redes existentes e permitirá abertura para novas interações. Parcerias bem acolhidas e necessárias para o fortelecimento do Programa INCT.

\section{Produção científica dos pesquisadores dos INCTs de Nanotecnologia}

A produção científica dos pesquisadores dos INCTs da área de Nanotecnologia foi analisada contemplando-se as seguintes variáveis: tipologia documental; produtividade; autoria; título, idioma e nacionalidade da fonte de publicação². Essas variáveis conduziram a análise e discussão dos resultados, os quais responderam ao terceiro objetivo específico da pesquisa: levantar a produção científica dos institutos selecionados no período que compreende os anos de 2008 a 2014, período de vigência dos institutos em sua primeira edição.

A tipologia documental foi indicada conforme encontrado na Plataforma Lattes, e assim discriminada: artigos completos publicados em periódicos nacionais e estrangeiros; livros publicados/organizados ou edições; capítulos de livros publicados; e trabalhos completos publicados e apresentados em anais de congressos. A título de padronização e busca pela uniformidade na tabulação dos dados desprendeu-se atenção à nomenclatura empregada para as variáveis.

Os ajustes realizados na nomenclatura da tipologia documental suprimiram as expressões longas e contemplou apenas palavras simples. A expressão artigos completos publicados em periódicos foi substituído pela palavra artigo. Os

2 Neste livro apresentamos apenas a tipologia documental da produção cientifica dos pesquisadores da área de Nanotecnologia, os dados completos da pesquisa podem ser consultados em Ferreira (2018). 
livros publicados/organizados ou edições passaram a ser identificados apenas como livros. Os capítulos de livros publicados foram especificados como capítulo. Os trabalhos completos publicados em anais de congressos foram apresentados apenas como anais e as apresentações de trabalhos em eventos como apresentação de trabalhos.

A quantificação total da produção científica coletada foi apresentada; o resultado desta coleta de dados representou a soma de 7.630 publicações e compreendeu: 3.054 artigos; 2.542 anais; 82 livros; 252 capítulos; 1.633 apresentações de trabalhos; 67 produções bibliográficas indicadas pelos pesquisadores como de tipos diversos; e 39 publicações recuperadas pelo software livre scriptLattes, mas sem indicação de ano, contudo.

A representação desta produção foi ressaltada no Gráfico 27. Os artigos, anais e apresentações de trabalhos foram as produções mais significativas dos pesquisadores dos INCTs da área de Nanotecnologia no período de 2008 a 2014. Essas produções perfizeram o total de 7.146 documentos. Percebe-se, ao observar o Gráfico 27, a prevalência dessas três tipologias documentais no período de coleta em decorrência do somatório que representam.

Gráfico 27 - Tipologia documental da produção científica

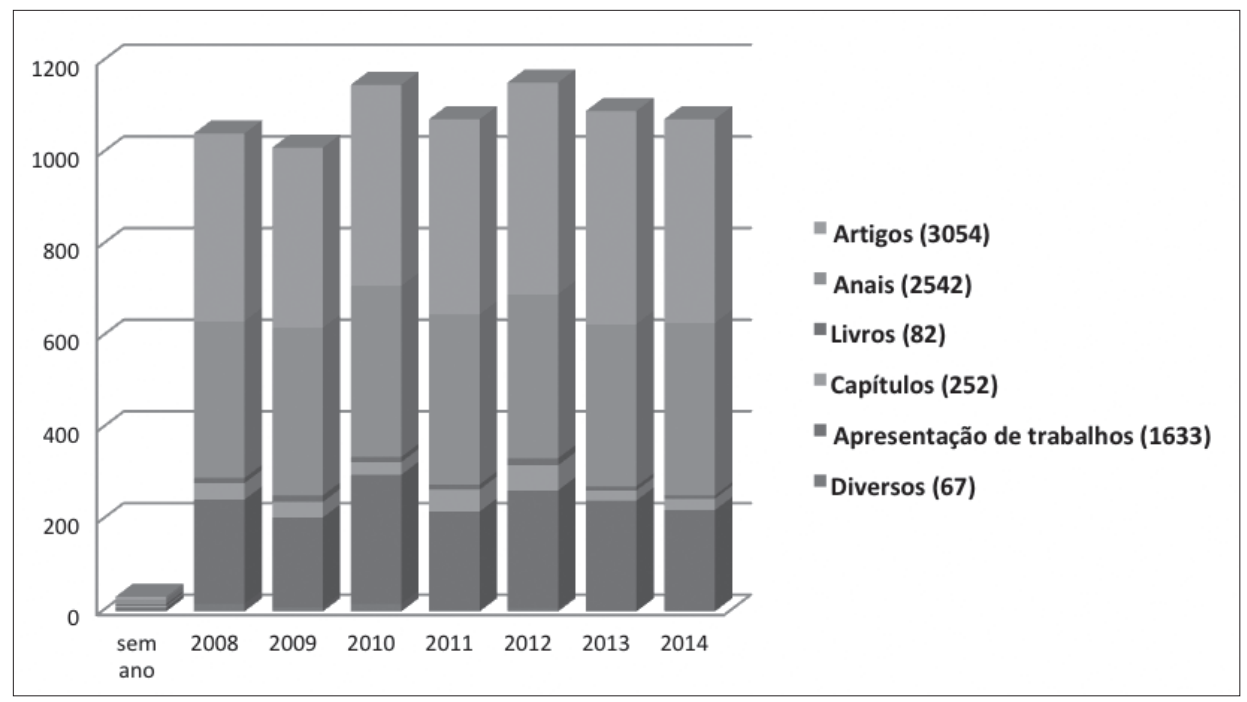

Fonte: Elaboração da autora. 
No conjunto em destaque ficou evidente, a supremacia da produção de artigos, em detrimento das outras tipologias. A produção dos anais aproximou-se em alguns períodos da produção dos artigos, especialmente no ano de 2009, no qual foi registrada a diferença de apenas 29 trabalhos. Esse resultado indicou uma cultura que privilegia a publicação em artigos na área investigada.

Os periódicos foram considerados por Mueller (2005) como o veículo mais usado para publicação pelos pesquisadores das áreas das Ciências Exatas, Biológicas, e da Saúde e os pesquisadores das Engenharias indicaram o uso desse veículo de modo intermediário. O resultado obtido na pesquisa contemplou as observações, por ter se registrado uma forte presença das Ciências Exatas, Biológicas e Engenharias no perfil dos pesquisadores analisados.

A produção de livros com um total de 82 publicações, e de capítulos de livros, 252 publicações foram pequenas na área se comparads com as outras produções; isso reforçou a assertiva de que estas tipologias documentais não possuem preferência para produção e divulgação dos resultados de pesquisa na área investigada. Constatou-se que a prioridade foi dispensada a produção de artigos de periódicos e trabalhos publicados em anais, resultado que se tornou relevante ao ser confrontado com o objetivo da pesquisa. Quanto maior a produção de artigos e participação em eventos, maiores as oportunidades para se fortalecerem as parcerias e se buscar novos trabalhos em colaboração.

Os motivos para a preferência pelas tipologias pontuadas pode tender para lados diversos, além dos pontuados por Mueller (2005). Apesar de essa análise não ser foco da pesquisa, sinalizou algumas suposições: predominância de pesquisadores com formação na área das ciências naturais, como comprovado na caracterização dos cientistas que atuam nos INCTs da área de Nanotecnologia. Essa predominância leva à preferência por divulgação da produção científica em artigos de periódicos e anais, veículos mais utilizados para comunicação científica nessas áreas. Entre as razões para a preferência creditam-se: a pontuação atribuída pelas agências de fomento quando da avaliação da área de pesquisa; a rapidez na divulgação e disseminação dos resultados de pesquisa, comparando-se aos outros veículos; fomento investido nos institutos revertidos em pesquisas que apresentam seus resultados nos artigos e anais. 
As inferências suscitadas com a análise do quantitativo geral da produção científica dos pesquisadores dos INCTs da área de Nanotecnologia foram apresentadas à medida que os resultados foram pontuados. Os artigos de periódicos registraram uma produção crescente com algumas oscilações nos anos analisados. Os anos de 2009, 2011 e 2014 sinalizaram um decréscimo,comportamento creditado ao atraso no repasse de verbas e quebra da motivação de alguns pesquisadores dos INCTs analisados. A incerteza quanto à continuidade do programa, em especial no ano de 2014, foi um dos motivos para a baixa produtividade.

A produção em anais manteve-se constante, com o registro de crescimento no ano de 2014, ao contrário dos artigos, que registraram uma queda na produção nesse ano. Conforme assertiva de Meadows (1999) as comunicações apresentadas em eventos são comuns na área das engenharias, outra área de formação presente no perfil dos pesquisadores dos INCTs de Nanotecnologia. A avaliação pelos pares de anais lhes confere um peso equivalente aos artigos de periódicos. Mueller (2005, p. 6) complementa "confirmando a literatura, os dados mostram que para as Engenharias, os anais de congressos são canais prestigiosos e frequentes na comunicação da área." As apresentações de trabalhos registraram um boom em 2010, mas a manteve-se constante partir desse ano. Em 2014, também registrou-se uma queda em sua produção.

Os livros registraram um comportamento de produção sempre baixo, acompanhados pelos capítulos dos livros por pequena margem de diferença. O período de maior produção de capítulos de livros foi em 2012 e daí em diante manteve-se constante. Um comportamento compreensível em uma área onde este veículo de comunicação científica não se encontra entre os preferidos. O Gráfico 28 registrou os resultados analisados. 
Gráfico 28 - Comportamento observado na produção científica

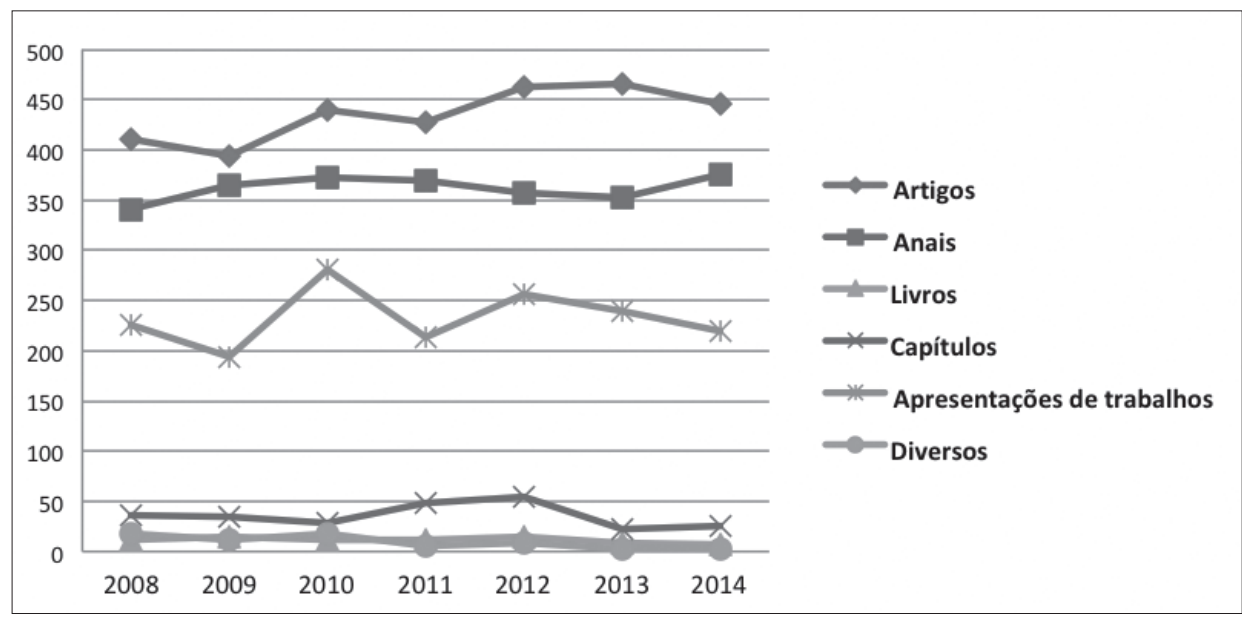

Fonte: Elaboração da autora.

O tratamento realizado nos dados da produção científica extraída da Plataforma Lattes pelo software scriptLattes atribuiu-lhes maior confiabilidade. Os dados foram conferidos e seu quantitativo contabilizado e padronizado.

Esse foi um trabalho árduo, mas necessário, devido ao porte da pesquisa realizada e à quantidade de dados recuperados, cuidado tomado com vistas a suprimir algumas inconsistências relativas a nome de autor, título do documento, topologia documental etc., apesar do tratamento contra redundâncias realizado anteriormente pelo software scriptLattes. As correções sanaram distorções quanto aos totais da produção e problemas de digitação no momento da inserção dos dados na Plataforma Lattes pelos pesquisadores dos INCTs da área de Nanotecnologia.

\section{Infraestrutura e suporte para pesquisa: INCTs e modelo e-Science}

Iidentificar a infraestrutura e suporte para pesquisa provenientes da implantação dos institutos da área de Nanotecnologia e sua correlação com o modelo de infraestrutura e-Science foi o quatro objetivo da pequisa realizada. Reconhecer os objetos que correspondiam ao coletivo das práticas colaborativas para inovação realizadas nos INCTs e sua relação de causa e efeito com o fenômeno da e-Science o complementou. 
Para a apresentação desses resultados, foi necessário destrinchar os elementos-chave desse objetivo e identificar os objetos que o caracterizavam. Na análise foram contemplados: o modelo INCT, política pública de fomento para pesquisa em Ciência Tecnologia e Inovação selecionada; e o modelo e-Science, como padrão para um fazer científico renovado, de práticas colaborativas voltadas para a pesquisa e todo o arcabouço tecnológico que o congregava.

Tomou-se como base para investigação a terceira fonte de incerteza, indicada por Latour (2012) como a natureza dos objetos. Os elementos que compunham a infraestrutura tanto dos INCTs quanto da $e$-Science, foram esmiuçados para contemplar o objetivo proposto.

O modelo INCT foi representado pelos institutos da área de Nanotecnologia contemplados na seção 3 desse livro. Essa seção continha as informações preliminares que os caracterizavam: a localização de sua sede, os pesquisadores que atuavam nos institutos e a natureza do grupo. A seção atual contemplou os outros indicadores que representavam o modelo e conduziram a análise do quarto objetivo específico da pesquisa como: a percepção do modelo INCT, na ótica dos seus membros; a infraestrutura existente para pesquisa e os recursos informacionais digitais utilizados pelos pesquisadores dos institutos.

Os depoimentos dos coordenadores entrevistados, intercalados com os achados dos relatórios de acompanhamento de projeto compuseram os resultados apresentados sobre a percepção acerca do modelo INCT, as razões que os influenciaram a participar do projeto e as vantagens obtidas com a experiência. O Quadro 16 contemplou os relatos.

Quadro 16 - Modelo INCT - Percepção

\section{MODELO INCT - PERCEPÇÃO}

na realidade para nós foi um processo natural porque nós já vinhamos trabalhando, eu comecei a trabalhar com Nanotecnologia em interação com grupos de outras áreas. [...]. E isso deu muito certo, porque a interação favoreceu com que o nosso trabalho andasse mais rápido, fizéssemos bons trabalhos e publicássemos mais. Quer dizer, quando você olha, você só vê vantagem naquela espécie de colaboração. [...] Quando veio o INCT nós já trabalhávamos como INCT, não como INCT mas como rede, então esse foi um processo absolutamente natural.

foi muito produtivo nesse sentido. Na área que nós trabalhamos, conseguimos juntar todas as pessoas que tinham atividades correlatas [...]. Reunimo-nos e pegamos gente especializada em várias atividades, várias instituições do país e nós conseguimos ter um avanço maior, porque nós conseguimos agregar conhecimentos afins [...] juntando competências de diferentes instituições. 
[...] são muito relevantes, são extremamente relevantes. É uma experiência muito bem sucedida, exatamente porque o Brasil é um país que não tem tantos recursos assim. Então nós temos que utilizar a forma otimizada de recursos e uma forma otimizada de usar os recursos é exatamente formar redes, está certo? E essa rede então nos permite usar esses recursos de uma forma mais eficiente e estimular a colaboração.

eu vejo como muito importante esse empreendimento, fortaleceu bastante a formação de recursos humanos, tanto dentro da rede, como ações externas como cursos, escolas para motivar jovens, outros estudantes de outra área ensinando, até divulgando a nossa área e orientações a respeito de como proceder à divulgação para estudantes e para a sociedade de um modo geral.

aqui o "efeito" INCT se fez sentir com bastante veemência, e acreditamos que esse objetivo foi alcançado com grande sucesso. [...] Em primeiro lugar, por tratar-se de um grupo multidisciplinar e interdisciplinar, os resultados que não poderiam ser obtidos por laboratórios isoladamente, por falta de expertise ou falta de equipamento, são alcançados de forma mais ágil e mais rápida.

desde a criação do instituto, as possibilidades de desenvolvimento de novos dispositivos otimizados se tornaram uma realidade com a inclusão da técnica de Algoritmo Genético no cálculo de projeto das amostras em estudo. Essa é uma área (inverse design) de ponta hoje em dia e a inclusão desse tema nas nossas atividades se mostrou bastante oportuna. A combinação de pesquisadores com experiência nessa técnica de Inteligência Computacional com outros de desenvolvimento de materiais e dispositivos, todos dentro do [...], possibilitará um avanço ainda maior na engenharia de materiais que envolvem o design de amostras específicas, de forma a obter o desempenho desejado do dispositivo.

[...] a fundação do INCT possibilitou uma concentração dos esforços brasileiros que aumentaram consideravelmente a qualidade das pesquisas desenvolvidas e permitiram alcançar o patamar internacional.

Fonte: Elaboração da autora.

Infere-se, com a análise dos resultados apresentados, que a implementação dos INCTs favoreceu e solidificou as redes de pesquisadores existentes e que atuavam em áreas correlatas à Nanotecnologia. Os institutos foram considerados como continuidade de ações que eram realizadas antes de sua criação. O Programa INCT foi um estímulo a mais para os pesquisadores e oportunidade de abertura de novas frentes de pesquisa que contemplavam a multidisciplinaridade apresentada; uma possibilidade de avanço significativo em áreas antes não apreciadas. Novas redes colaborativas também foram constituídas e os saldos para um programa dessa magnitude foram positivos. A inovação presente no desenvolvimento de novos dispositivos tornou-se realidade e vários foram os aspectos citados que direcionaram para essa assertiva. Dentre esses os abaixo listados:

- agregação de pesquisadores com atividades correlatas;

- agregação de pesquisadores com especialidades distintas; 
- agregação de pesquisadores de instituições diversas do país;

- maior avanço na pesquisa, especialmente em áreas antes não contempladas;

- agregação de conhecimentos afins e competências de diferentes instituições;

- otimização de recursos;

- fortalecimento na formação de recursos humanos;

- desenvolvimento de tecnologia inovadora;

- fortalecimento do trabalho em redes colaborativas.

Conforme previsto pela Portaria MCT No 429, de 17 de julho de 2008, os INCTs deveriam ser formados em uma instituição sede, caracterizada pela excelência de sua produção científica e tecnológica, alta qualificação na formação de recursos humanos e com capacidade de alavancar recursos de outras fontes, e por um conjunto de laboratórios ou grupos associados de outras instituições, articulados na forma de redes científico tecnológicas (BRASIL, 2008).

O Edital n ${ }^{\circ}$ 15/2008 do MCT indicou as características que deveriam ser contempladas pela instituição sede conforme foi apresentado.

A instituição sede, caracterizada pela excelência da produção científica e tecnológica, alta qualificação na formação de recursos humanos deve:

- demonstrar que já tem capacidade de captar recursos de outras fontes;

- dispor de espaço físico e infraestrutura que possibilitem uma caracterização visível do Instituto Nacional;

- garantir o uso da estrutura física e participação de pesquisadores e técnicos no desenvolvimento do projeto e, quando pertinente, oferecer recursos de contrapartida para o desenvolvimento do mesmo, por documento da autoridade maior (CNPq, 2008).

A infraestrutura existente no INCT disponibilizada pela instituição sede identificada nos relatórios compreendeu em sua maioria: o espaço físico para 
reuniões e encontros eventuais entre os pesquisadores; o acesso às instalações da sede e a disponibilidade para o uso de telefone, computador e internet; espaço físico para construção de laboratório; equipamentos específicos para as pesquisas realizadas; e um funcionário de apoio contratado por alguma fundação, ou designado pela instituição.

O Quadro 17 indicou os resultados obtidos de acordo com os INCTs investigados e permitiu avaliar se a infraestrutura oferecida estava alinhada com as exigências do edital 15/2008.

Quadro 17 - Infraestrutura INCT

\begin{tabular}{|l|l|}
\hline \multicolumn{1}{|c|}{ INFRAESTRUTURA INCT } \\
\hline DISSE & $\begin{array}{l}\text { sala de reuniões, auditório para workshop, espaço físico } \\
\text { para construção de um laboratório onde foi instalado o } \\
\text { novo equipamento de epitaxia (CONSELHO NACIONAL DE } \\
\text { DESENVOLVIMENTO CIENTÍFICO E TECNOLÓGICO, 2013f). }\end{array}$ \\
\hline \multirow{5}{*}{ NAMITEC } & $\begin{array}{l}\text { uma sala, um funcionário contratado, acesso ao uso do telefone, } \\
\text { impressão, e infraestrutura geral da instituição (CONSELHO } \\
\text { NACIONAL DE DESENVOLVIMENTO CIENTIIFICO E TECNOLÓGICO, } \\
\text { 2014b). }\end{array}$ \\
\hline NANOBIOTECNOLOGIA & $\begin{array}{l}\text { computador, impressora a leser e uma secretária. A infraestrutura } \\
\text { criada pelo INCT juntou-se aos recursos do Pro-Infra Finep para } \\
\text { construção de um prédio onde foi disponibilizado área para dois } \\
\text { laboratórios de Nanotecnologia. Equipamentos para métodos } \\
\text { de caracterização e para realização de testes in vitro e in vivo } \\
\text { (CONSELHO NACIONAL DE DESENVOLVIMENTO CIENTÍFICO E } \\
\text { TECNOLÓGICO, 2013d). }\end{array}$ \\
\hline NANOCARBONO & $\begin{array}{l}\text { espaçO físico para reuniões do comitê gestor e infraestrutura para } \\
\text { comunicações entre os membros deste comitê como: telefone e } \\
\text { internet. Um professor adjunto contratado. Implementação do Centro } \\
\text { de Tecnologia em Nanotutos (CT-Nanotubos) (CONSELHO NACIONAL } \\
\text { DE DESENVOLVIMENTO CIENTÍFICO E TECNOLÓGICO, 2013e). }\end{array}$ \\
\hline
\end{tabular}

Fonte: Elaboração da autora.

Os resultados obtidos confirmaram que as exigências foram contempladas e a infraestrutura oferecida pela instituição sede estava de acordo com o que foi previsto no Edital no 15/2008. Configurou-se, desse modo, a observância entre o que foi exigido no edital citado e o que foi apresentado pelos INCTs. 
Para identificar a infraestrutura para pesquisa disponível nos institutos foi necessário resgatar o modelo de infraestrutura e-Science e fazer um contraponto. Não se utilizou um modelo que correspondesse à realidade da infraestrutura e-Science no país, devido à dificuldade para se obter resultados consolidados de iniciativas que caracterizassem o modelo pretendido. Contudo, utilizou-se como parâmetro a iniciativa do Programa $e$-Science implementada pela FAPESP, no que concerce a políticas de fomento a pesquisa, analisado na próxima seção desse livro.

O resgate dessa infraestrutura na literatura científica consultada imprimiu segurança à análise realizada. A infraestrutura e-Science, segundo Andronico e colaboradores (2011) foi denominada como e-infraestructure, ou seja, "um 'método científico' que prevê a adoção de plataformas digitais de ponta conhecidas como infraestruturas eletrônicas em todo o processo, da ideia à produção do resultado científico. Segundo os autores citados, essa infraestrutura eletrônica pode ser conceitualmente representada por três camadas:

- parte inferior, composta pelos instrumentos científicos e experimentos que fornecem grande quantidade de dados;

- em seguida, a camada de rede, centros de processamento de dados em rede e software middleware como a "cola" dos recursos;

- e o terceiro e mais alto nível que inclui pesquisadores que realizam suas atividades independente da localização geográfica, interagem com os colegas, compartilham e acessam os dados (ANDRONICO et al., 2011).

A representação das camadas da e-infraestructure apresentadas no capítulo que trata sobre a $e$-Science foi contemplada pela Figura 11, resgatada do contexto de apresentação inicial. 
Figura 11 - Modelo de Infraestrutura e-Science

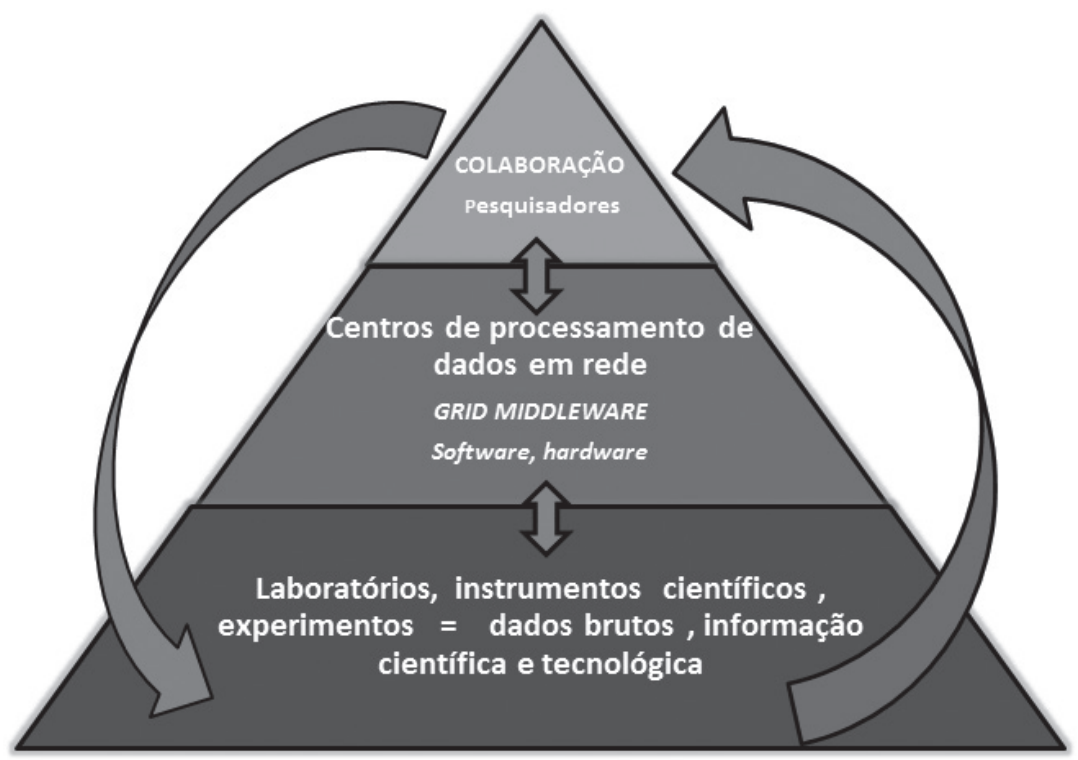

Fonte: Elaboração da autora baseada em Andronico e colaboradores (2011).

Esse aparato caracterizou uma infraestrutura voltada para grandes projetos colaborativos que envolviam a troca de volumes de dados em grande escala. Identificar nos INCTs a existência de uma infraestrutura tecnológica compatível com a prevista em um modelo $e$-Science perpassava a verificação dos serviços de suporte e infraestrutura para pesquisa e tratamento de dados por eles oferecidos, utilizados e mantidos em suas atividades colaborativas.

O questionamento relacionado a quais serviços eram contemplados pelos INCTs, dentro desses parâmetros, auxiliaram no diagnóstico pretendido. Registrou-se como o suporte mais sinalizado a indicação para os serviços de citação, publicação e distribuição de dados (29,7\%). Computou-se ainda a indicação para repositórios de dados (22\%); para as bibliotecas digitais (16,5\%); para a integração de dados (14\%), e para os colaboratórios (12,1\%). O grande destaque nos resultados obtidos recaiu sobre a sinalização para as respostas "nenhuma das opções indicadas" e "desconheço esses termos utilizados”, cuja soma dos percentuais representou $42,9 \%$ do total obtido entre todas as opções indicadas. O Gráfico 29 ilustrou o resultado obtido. 
Gráfico 29 - Serviços oferecidos no INCT X Infraestrutura e-Science

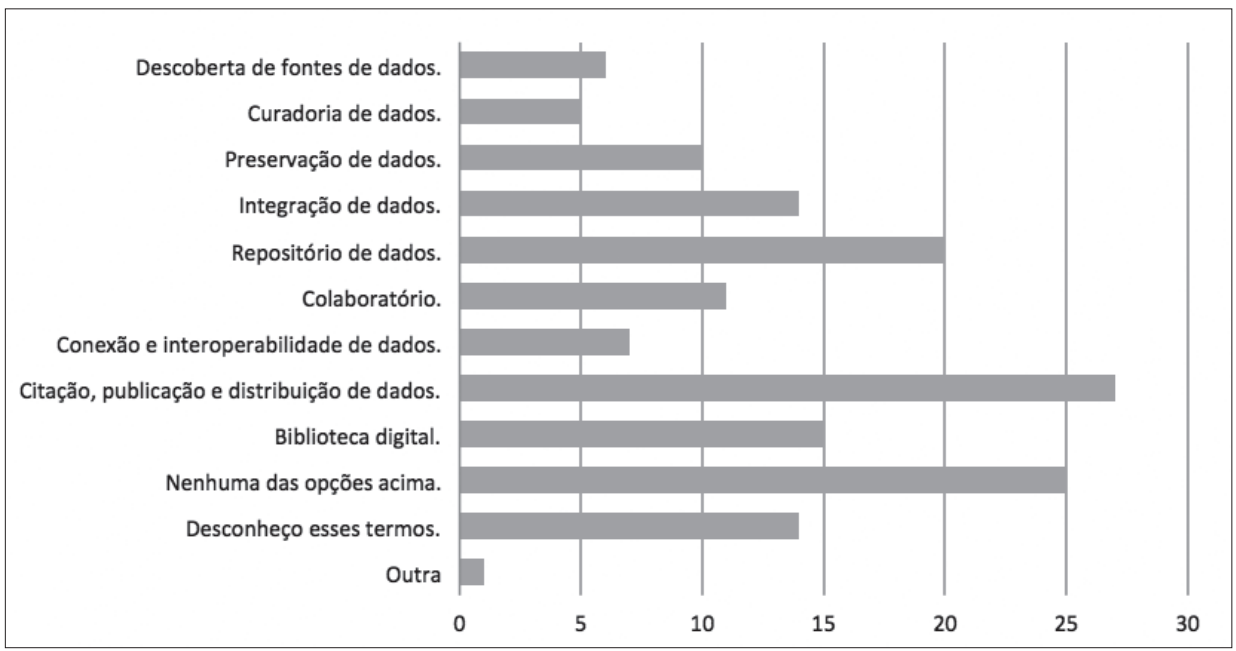

Fonte: Elaboração da autora.

Esse resultado permite afirmar que a existência de serviços característicos da infraestrutura e-Science é incipiente nos INCTs da área de Nanotecnologia investigados. Apesar do registro de existência de repositórios de dados, bibliotecas de dados e colaboratórios, o percentual foi relativo quando se leva em consideração as indicações de inexistência e desconhecimento sobre os termos que caracterizavam o serviço.

Quando questionados sobre a comparação entre a infraestrutura do INCT com o modelo de infraestrutura e-Science, os coordenadores consideram que o modelo e-Science não era estruturante das práticas colaborativas realizadas nos institutos, em sua maioria. Exceto um declarou que o INCT a que estava vinculado se enquadrava no modelo. Entretanto, concluiu-se que o fato de o conceito ser novo e desconhecido para o grupo investigado, conforme atestaram os pesquisadores em resposta a questionamento sobre o assunto, a prontidão na resposta gerou dívidas. Acredita-se que deve ter havido confusão com o significado exato do termo e sua real aplicação, o que suscitou imprecisão no momento da resposta. Os trechos destacados foram apresentados na sequência:

[...] não, ainda não fazemos uso dessas tecnologias.... não no nosso caso ainda não; 
nós do [...] nos enquadramos nesse modelo. O que fazemos, nós temos um grupo dentro do INCT, nós temos colaboradores que nessa parte de tecnologias de comunicação, [...] são bem focados nessa área. Então eles na realidade difundem dentro do grupo essas práticas digamos assim. Mas digamos não é todo mundo que está envolvido, aí eles tentam de tudo... esse grupo mais especializado digamos mais perto da e-Science, eles tentam nos puxar;

[...] pelo menos por enquanto não, até poderá vir a ser, é uma coisa interessante, o mundo está ficando cada vez mais baseado nessas trocas de informações através dos meios eletrônicos, mas no nosso INCT, eu the digo francamente que não foi algo estruturante;

nós usávamos o webc também para fazer reuniões e usávamos um site para repositório, no laboratório, mas nada assim como um estudo sobre a tecnologia e-Science. Nós usamoos as ferramentas;

A tecnologia ajuda mas não é...

Infere-se, com os resultados obtidos que não existe adequação entre a infraestrutura para pesquisa nos INCTs da área de Nanotecnologia e a infraestrutura $e$-Science, apesar de existirem alguns elementos semelhantes entre os dois modelos, como por exemplo, o aporte financeiro significativo da iniciativa pública e o forte perfil colaborativo apresentado nas redes colaborativas. Conclui-se, desse modo, que o quarto objetivo específico foi contemplado quando se respondeu ao questionamento realizado sobre a infraestrutura e suporte para pesquisa presentes nos INCTs e sua atenção ao solicitado pelo Programa INCTs.

Observou-se, ampla utilização dos recursos informacionais digitais, o que pode ter favorecido a interpretação dos coordenadores quanto à adequação do modelo INCT ao modelo e-Science. A indicação da utilização desses recursos reforçou a assertiva de que os pesquisadores dos INCTs de Nanotecnologia são usuários ativos dos artefatos tecnológicos contemporâneos. Entretanto, isso não os caracteriza como pesquisadores que desenvolvam projetos os quais utilizam grandes volumes de dados para a realização de suas práticas colaborativas, nem que esse seja o alvo predominante de suas pesquisas.

Os artefatos tecnológicos contemporâneos indicados foram: e-mail, Skype, redes sociais, intranet, internet e alguns softwares proprietários de compartilhamento 
de recursos digitais e apoio na realização de videoconferência. O Quadro 18 contemplou a indicação dos artefatos utilizados, conforme informações dos coordenadores dos INCTs.

Quadro 18 - Recursos informacionais digitais

\section{RECURSOS INFORMACIONAIS DIGITAIS}

não, nós temos uma intranet, uma rede nossa, nós usamos Facebook, Twiter...., e as redes sociais. Nós temos um desenvolvido por nós, uma intranet, uma rede nossa que junta todos os grupos, e tem esse software que te falei que é como se fosse um laboratório virtual que nós colocamos todos os dados, todo mundo tem acesso.

webs, e-mail, Skype, Google Docs, na elaboração de propostas, de artigos.

não, apenas uma minoria é que trabalha, a maioria não. Temos a ferramenta, oferecemos, divulgamos, mas assim, a verdade é que ela foi usada apenas por uma minoria de pesquisadores.

nós utilizávamos várias práticas que utilizam meios de comunicação [...]. Por exemplo, um software que usamos e colocamos as informações sobre as amostras que produzimos, os resultados, às vezes nos produzimos uma amostra, distribuímos para vários grupos que fazem investigações diferentes das mesmas amostras. Nós temos um banco de dados, digamos assim...

basicamente Skype e o e-mail, normalmente as informações que nos temos, quando tem alguma discussão. Essa discussão ou é feita por Skype ou é feita por e-mail, mas eu lhe digo novamente, isso às vezes é uma deficiência do coordenador ou da coordenação muito mais do que do grupo. Porque o grupo me cobra, vamos fazer isso, vamos fazer aquilo, agora só me cobrar não resolve.

Fonte: Elaboração da autora.

Os resultados obtidos permitiram a idealização do desenho, do modelo da infraestrutura INCT baseado nas práticas colaborativas para inovação e diversas interações identificadas, o qual fundamentou-se, para sua execução, nos depoimentos e resultados obtidos ao longo da pesquisa. Esse modelo foi formado por uma sede que representava a sua base, a qual era composta pela instituição sede dos INCTs e responsável pelo instrumental físico colocado à disposição dessa; e para representar o seu topo um grupo de pesquisadores concentrados em realizar as pesquisas e as interações com a camada intermediária. Embora ocorresse comunicação também com a camada intermediária, ambos estavam ligados diretamente à base.

A camada intermediária foi composta pela rede das práticas colaborativas entre os diversos atores/actantes identificados. Ela representou as conexões e 
interações entre estes nós e os pesquisadores dos INCTs, entre os quais encontravam-se: as universidade; as instituições; as organizações; as empresas; os laboratórios; os hospitais; as políticas; e os agentes de fomento. Todps esses responsáveis pela infraestrutura científica e tecnológica utilizada e compartilhada pelos pesquisadores dos INCTs da área de Nanotecnologia. Entretanto, na sede do INCT também se encontrava parte da infraestrutura utilizada nas colaborações. O modelo foi apresentado na Figura 12.

Figura 12 - Modelo de infraestrutura INCT

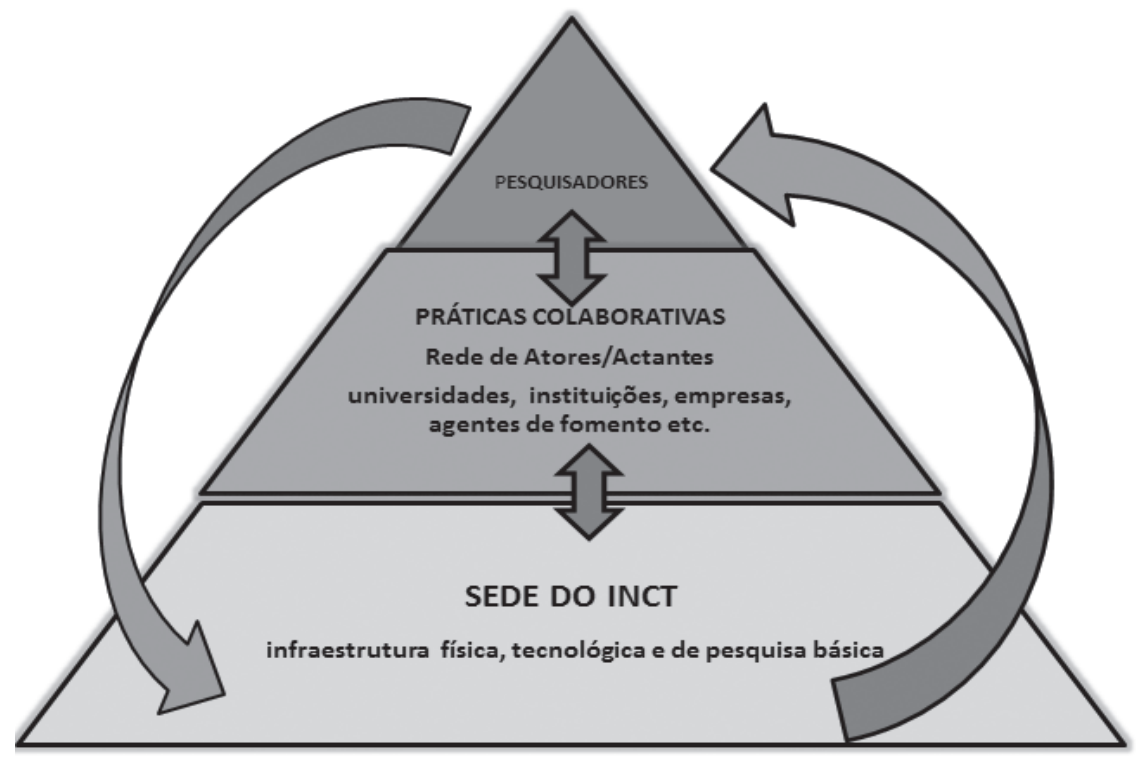

Fonte: Elaboração da autora.

Identificar a infraestrutura existente nos INCTs representou a primeira medida para identificar o modelo existente e poder compará-lo com o modelo $e-S$ cience. A próxima ação foi entender a noção predominante do termo e-Science nos institutos, o que permitiu entender o porquê de pesquisadores cujo perfil inclui a atuação com elementos da alta tecnologia, maioria, não realizarem projetos nos moldes e-Science.

O entendimento sobre o termo e-Science que predominou foi o de um conjunto de ferramentas e tecnologias necessárias para apoiar a pesquisa. Essa res- 
posta representou o percentual 59,3\%. e a noção do termo como metodologia de pesquisa científica obteve o percentual de $22 \%$ de respostas.

As opções para o entendimento do termo e-Science como uma nova forma de fazer ciência; e como um novo paradigma da ciência (quarto paradigma) corresponderam respectivamente a $17 \%$ e $9,9 \%$ das respostas obtidas. O Gráfico 30 apresentou o resultado completo.

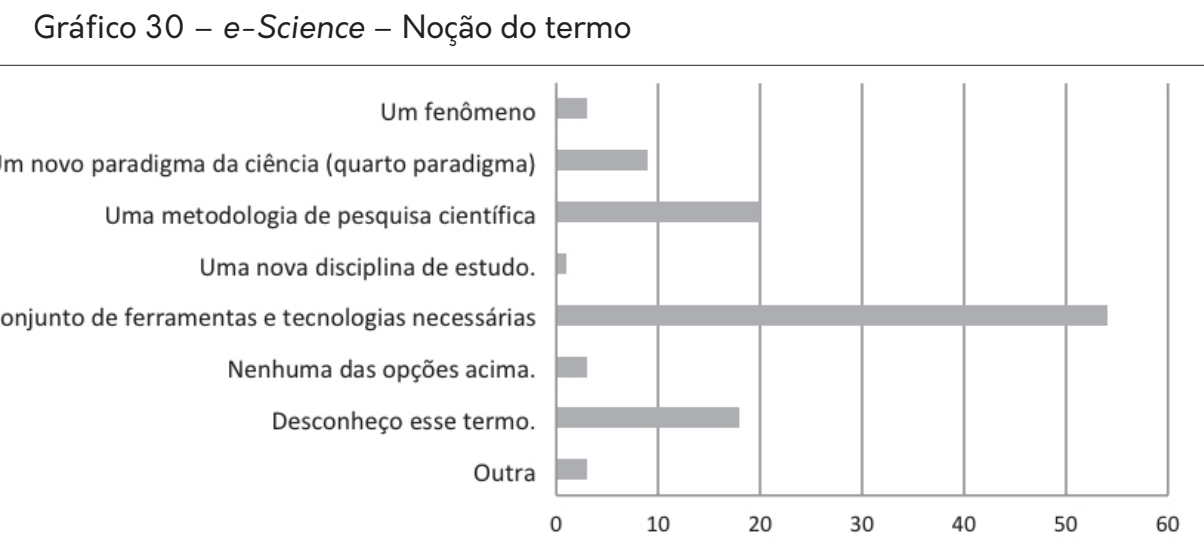

Fonte: Elaboração da autora.

As respostas sinalizaram o fato de os pesquisadores da área em investigação não serem totalmente leigos em relação ao termo $e$-Science. Isso se justifica por se tratar de uma área que inclui profissionais cujo perfil indica competência no trato com as tecnologias de informação e comunicação e, desse modo, estarem bem informados para as inovações da área. A despeito disso, parcela significativa ainda desconhece o termo (19,8\%), o que também se justifica pela multidisciplinaridade característica da área, a qual contempla profissionais que atuam em outras frentes de atuação em que, apesar de ser utilizada, a alta tecnologia não é objeto de discussão nem estudo.

A questão referente à noção do termo e-Science também foi alvo de pergunta, aos coordenadores dos INCTs nas entrevistas online realizadas; os resultados obtidos foram indicados a seguir, nos trechos destacados:

não, esse termo não como conceito...., como termo, eu com certeza posso falar pela maioria dos meus colegas, eles não conhecem. É um termo realmente novo; 
esse termo e-Science, nós não.... nunca falamos nele. No INCT, nas reuniões que fazemos nunca foi comentado. [...] Usamos essas metodologias e a comunicação eletrônica, mas o termo e-Science propriamente dito nós nunca utilizamos;

[...] acho que nunca usamos muito esse conceito;

bom com relação ao termo em si você vê, eu mesmo que sou coordenador nunca tinha ouvido falar.

Evidenciou-se, desse modo, o desconhecimento do termo $e$-Science entre os pesquisadores dos INCTs investigados, uma constatação que reforça a assertiva que justificou a não correlação do modelo INCT, com o Modelo de infraestrutura e-Science. Pelo menos, a infraestrutura identificada não contemplou a existência de um centro de processamento de dados responsável pela captura, curadoria e análise de grandes volumes de dados brutos e informação científica e tecnologia componentes da infraestrutura $e$-Science.

Questionou-se ainda sobre a existência de uma política, nos INCTs que contemplasse a gestão dos dados brutos, científicos e tecnológicos, uma das competências dos programas e-Science. Os resultados obtidos sinalizaram para o desconhecimento sobre a política e sua inexistência. O percentual das duas respostas somadas correspondeu a $68 \%$. O Gráfico 31 registrou o resultado obtido.

Gráfico 31 - Política para gestão de dados

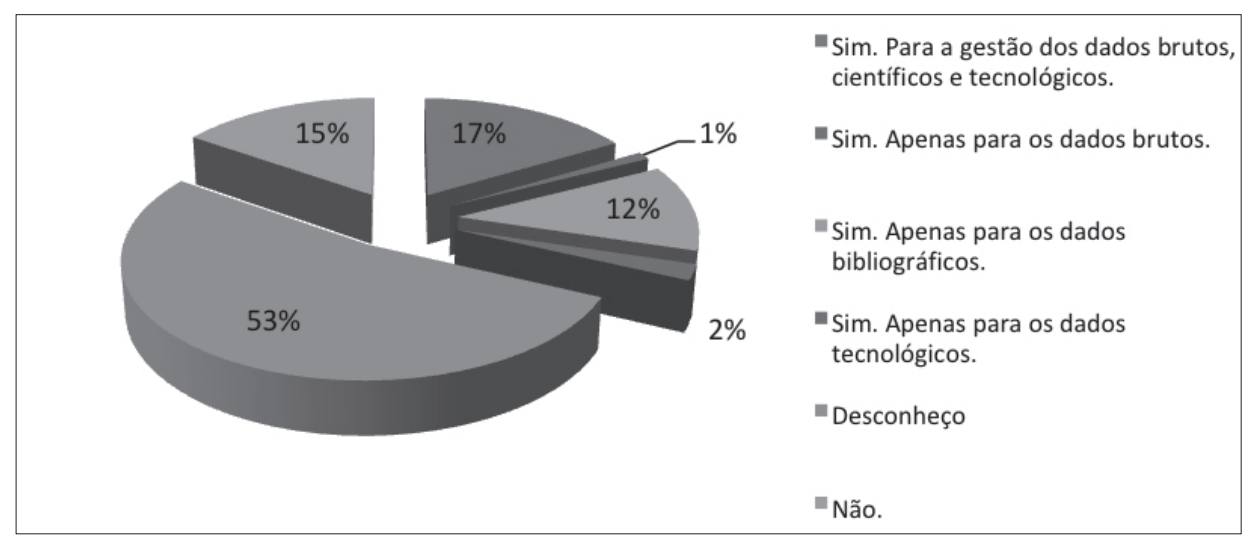

Fonte: Elaboração da autora. 
Os resultados foram coerentes por não existir uma infraestrutura que contemple esta questão, conforme os achados anteriores. Entretanto, esse resultado foi preocupante porque apesar de os INCTs não atuarem nos moldes do modelo e-Science, os pesquisadores que nele atuam desenvolvem pesquisa de alto nível e necessitam de um suporte para gerir e preservar o produto resultante das práticas realizadas.

A indicação da gestão dos dados, em sua plenitude, foi registrada apenas por $17 \%$ dos respondentes; dados bibliográficos (12\%); gestão dos dados tecnológicos (2\%); e parcela insignificante (1\%) para os dados brutos. Esses pontos requerem observação, tanto no que se refere aos produtos bibliográficos quanto aos tecnológicos, e especialmente os dados brutos, por se configurarem insumos passíveis de tratamento, curadoria e preservação. Principalmente por se tratarem de institutos com elevado índice de produção científica, justifica-se a preocupação com uma política que realize a gestão desses dados, obtidos como resultado do seu fazer científico. Os depoimentos obtidos com relação essa questão da gestão dos dados produzidos foram contemplados no Quadro 19.

Quadro 19 - Política para gestão dos dados de pesquisa

\section{POLÍTICA PARA GESTÃO DOS DADOS DE PESQUISA}

bom em relação aos resultados da pesquisa sim, quer dizer as publicações.... Nós temos arquivos e mantemos quais foram as publicações, quais foram os alunos que foram formados na formação de $\mathrm{RH}$ e como falei nós temos essa gestão dos dados a respeito das amostras. Os resultados que obtemos colocamos no gerenciador, digamos das amostras, dos nossos produtos. Poderíamos usar até mais... mas usamos. Nós temos essa política de gerenciamento.

é...isso nós já comentamos que nós disponibilizamos, divulgamos em nosso site. Basicamente isso, todo mundo sabe o que estamos produzindo com isso busca-se estimular a transformação dos livros.

[...] mas como as comunicações estão nos bancos de dados de nível alto, por exemplo, as sociedades científicas consolidadas, dificilmente essas sociedades serão quebradas. [... Suponho que eles tenham isso replicado algumas vezes.

[...] da mesma forma, tratamos essa informação da mesma forma que tratávamos a muito tempo, de uma forma não profissional. Chega ao final do ano compilamos todos os dados ou os dados mais importantes que foram adquiridos, dentro do INCT.[...]. Agora ter compilada e fazer gestão desse conhecimento são coisas bem distintas.

essa gestão não é feita, se você disser que teria interesse, é claro que teríamos interesse, interesse de alguém que inclusive mostrasse novos caminhos, a partir disso você poderia fazer isso e é impossivel você achar que você sabe tudo e pode fazer tudo. 
[...] basicamente o que nós fizemos foi o seguinte [...] nós conseguimos que o nosso site conversasse com o Lattes, para obter os dados do Lattes.

eu acho que respondendo a sua pergunta, do ponto de vista interno a dificuldade era assim, nos conseguirmos informações das pessoas, então por isso que no nosso caso conseguimos que o nosso site nos desse a informação das pessoas e por outro lado, pelo lado da administração, da coordenação dos INCTs eu acho que é uma verdadeira bagunça, com relação a essa gestão da base de dados.

Fonte: Elaboração da autora.

A e-Science surgiu de uma necessidade urgente de se enfrentar o "dilúvio de dados" e popularizou uma nova metodologia de pesquisa, desenvolvida em diferentes lugares, com uma história ainda imprecisa, denominações e grafias distintas, flexíveis e ainda tênues, mas com um objetivo comum, o uso de tecnologias de computação em rede para melhorar a colaboração e os métodos inovadores de investigação (WHITMIRE, 2013). A assertiva apresentada reforçou a percepção da convergência entre a tecnologia de computação, e as práticas colaborativas para inovação utilizadas no fazer científico.

Entretanto, esta metodologia de pesquisa não foi identificada nas práticas colaborativas realizadas pelos pesquisadores dos INCTs de Nanotecnologia, conforme os resultados atestaram. A gestão dos dados de pesquisa nos moldes dessa metodologia, a qual é uma das atividades contempladas pelo aparato tecnológico disponibilizado pela infraestrutura da $e$-Science, muito menos.

Identificou-se comportamentos distintos nos INCTs relacionados a gestão ds dados de pesquisa. Existem coordenações que procuram dar um tratamento aos dados produzidos, mesmo de forma rudimentar, apesar de terem consciência da necessidade de um tratamento especializado. Não o fazem, entretanto, por motivos diversos, dentre eles a inexistência de pessoal qualificado para essa tarefa e pelo fato de a gestão desses dados não ser o foco central de preocupação do instituto.

Algumas coordenações fazem a gestão dos dados de modo mais qualificado. Entretanto, não têm consciência de que estão realizando esta atividade. Algumas coordenações, a despeito de considerarem que estão tratando os dados, fazem-no de modo impróprio. Acreditam estarem protegidos contra perdas 
futuras por estarem vinculados a instituições, as quais teoricamente deveriam contemplar uma política de gestão dos dados produzidos.

Ao se concluir que os INCTs não realizavam uma política que contemplasse a gestão dos dados de pesquisa produzidos, nos moldes da e-Science, apesar de terem conhecimento, em parte, dessa necessidade, buscou-se identificar qual era a utilização dos dados brutos de pesquisa ou dos resultados obtidos. Os depoimentos dos coordenadores os contemplou.

[...] nós utilizamos os dados também, os dados da pesquisa. Por exemplo, nós fazemos umas medidas elétricas, medidas óticas e esses resultados estão disponíveis, todo mundo pode pegar;

[...] esses projetos centrais eles tem continuidade o tempo todo [...] Ou seja, a partir da informação um, que foi o desenvolvimento da nano, nós vamos buscando, cercando tudo que possa se relacionar com aquilo. Então tem coisas que começaram antes do INCT e ainda continuamos fazendo até hoje;

[...] então as pessoas fazem artigos e os artigos com seus resultados. Os resultados nunca são apresentados na forma de relatórios sempre é na forma de artigos.

Os relatos apresentados retrataram um grupo, o qual dentro das suas possibilidades aproveitam os dados brutos de pesquisa. Entretando, precisam submetê-los ao tratamento adequado para um reaproveitamento satisfatório por parte dos pesquisadores dos INCTs e disponibilizá-los a outros pesquisadores que demonstrem interesse. O destino atribuído aos dados configura-se em um problema sinalizado por Gray e Szalay (2007) quando ele observa que "um dos problemas é que todo projeto acaba num certo ponto e não está claro o que acontece com os dados."

Finaliza-se a apresentação dos dados pertinentes à manutenção de uma infraestrutura e suporte para os dados produzidos de pesquisa; o questionamento recaiu sob a atuação das agências de fomento. Os resultados foram contemplados no Gráfico 32. 
Gráfico 32 - Agências de fomento - Atuação

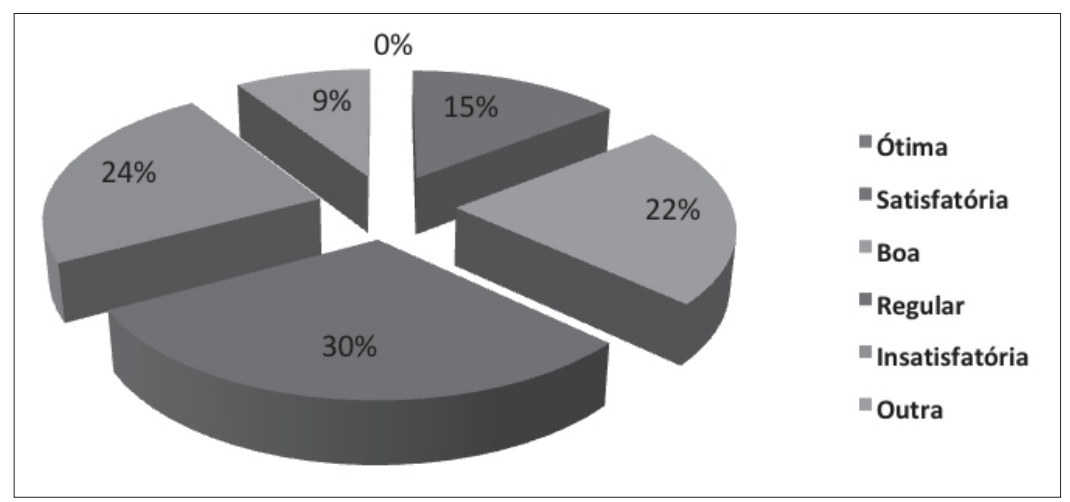

Fonte: Elaboração da autora.

Os resultados representaram que a atuação das agências de fomento não é satisfatória, ao menos no que diz respeito à infraestrutura de pesquisa, opinião correspondente a $30 \%$ das respostas obtidas, a qual evidencia a necessidade de mudanças nessa direção. $\mathrm{O}$ trabalho a ser feito é muito grande e o fornecimento efetivo de um arcabouço financeiro e tecnológico que satisfaça às reais necessidades dos pesquisadores e instituições associadas é premente

Os agentes de fomento que fazem parte da rede de práticas colaborativas para inovação dos INCTs de Nanotecnologia, possuem uma responsabilidade enorme que vai muito além do suporte financeiro. Os atores que desempenharam o papel de mediador, especialmente, ao atuarem de modo imprevisível e modificado no curso previsto nos acordos contemplados. A manutenção de atitudes, as quais primem pela pontualidade e constância no cumprimento dos acordos firmados serão bem acolhidas e certeza de metas cumpridas. Essa garantia favorecerá cada vez mais para que as políticas públicas voltadas para a CT\&I obtenham êxito.

Atitudes desse porte contribuem para: continuidade das políticas públicas implementadas e certeza na obtenção de um percentual de aprovação, o qual atinja até mais do que os 30\% resultantes de uma boa atuação; os agentes de fomento interferido favoravelmente na manutenção das políticas públicas como garantia no alcance de margens mais significativas de benefícios para todos os envolvidos na parceria; 
As políticas públicas voltadas para o fomento à CT\&I no Brasil são muito importantes para o desenvolvimento das pesquisas; para a o fornecimento de recursos e manutenção de suporte e infraestrutura; para a formação de recursos humanos e incentivo à transferência de conhecimento e tecnologia. Contudo, o cenário científico está repleto de controvérsias resultantes de tomadas de decisões e ações conflitantes em alguns momentos, a exemplo de: as agências de fomento que incentivam a colaboração, mas propiciam, ao mesmo tempo, a disputa por uma produção mais representativa entre os pesquisadores em termos qualitativos individuais; incentivam a colaboração, mas exigem que alguns comitês sejam compostos por pesquisadores exclusivamente de áreas específicas.

O comportamento dos diversos atores/actantes que interagem nesse contexto de práticas colaborativas representam as forças e conflitos em atuação. Os depoimentos dos coordenadores permitiram entender um pouco mais sobre a visão que possuem sobre as políticas públicas e sua repercussão nos INCTs de Nanotecnologia. Os resultados obtidos foram apresentados no Quadro 20.

Quadro 20 - Políticas Públicas - Relevância

\section{POLÍTICAS PÚBLICAS}

bom eu discordo um pouco... eu acho que no caso particular do meu INCT a política funcionou... Eu, na realidade, para falar a verdade eu acho que não funcionou [...] Até agora funcionou como qualquer outra iniciativa anterior do governo, porque uma política pública, no sentido do termo política pública, para mim é uma coisa de longo prazo que você investe na manutenção de um modelo e isso na realidade não foi feito.

eu não vejo o INCT como uma política pública porque se fosse uma política pública teria uma continuidade e é uma coisa que na vida inteira eu não vejo nenhuma diferença. Você faz um projeto grande, um grande investimento como foi feito anteriormente no PRONEC, depois teve os Institutos do Milênio etc e dá um grande volume de recursos, todo mundo fica feliz, depois não tem mais recursos para manter o investimento inicial feito.

[...] antes tinha sim, nós tinhamos o, digamos o Instituto do Milênio com as duas fases anteriores, eles tiveram um Instituto do Milênio bem parecido com os INCTs, bom talvez com um vigor menor, pois aprendeu-se com os Institutos do Milênio. Um estímulo maior para formação de recursos humanos a passar, estimular a passar conhecimento para a sociedade e para os recursos humanos.

isso é uma pergunta meio complicada, o próprio INCT já é um política pública que faz com que as colaborações tenham um outro patamar. Patamar extremamente elevado. Isso eu concordo, por si já é uma política que faz isso acontecer. Agora não necessariamente todas as outras políticas públicas tenham a ver com melhorar essa política de colaboração dos INCTs certo? 
não precisa ficar investindo toda hora mas você tem que no mínimo manter o investimento feito. Não mantém nada e tudo fica obsoleto, depois vem um outro programa e daí você renasce das cinzas e a cada cinco ou seis anos você tem que renascer das cinzas e na realidade por enquanto, os INCT estão no mesmo barco.

[...] você diz, olha você tem que colaborar por um lado, mas por outro você faz com que o sistema não ..... olha colabore aqui, mas aqui você vai ser penalizado porque você está colaborando. Isso aqui vale para alguns CAs do CNPq também. O que é que eu estou querendo te dizer com isso é que algumas, a maioria das políticas públicas elas te forçam a fazer colaboração, mas algumas penalizam quando você está fazendo colaboração.

bom eu acho que são muito relevantes, eu acho que são extremamente relevantes.

[...] talvez de grupos individuais, não necessariamente do INCT, algumas sim, algumas ajudam bastante nessa política de colaboração, outras não necessariamente em relação aos INCT, outras.... Ai às vezes tem o problema de bipolaridade das políticas públicas brasileiras.

de fato você publicar artigo com quatro, cinco pessoas, e na nossa área é impossível você publicar com menos do que isso pelo menos, e você é penalizado porque você esta publicando com muitas pessoas, você está entendendo?

[...] a questão da bipolaridade, mas no geral eu acredito que sim, no geral eu acredito que no processo de avaliação as políticas são propositivas no sentido da colaboração mas as vezes no processo de avaliação sua ou da pós-graduação em que você está inserido você é penalizado pos isso. É uma coisa que o sistema teria que repensar, e isso acontece não por causa do CNPq ou da Capes mas acontece por causa de pessoas.

Fonte: Elaboração da autora.

A política pública, no que se refere aos INCTs, foi válida, entretanto, existem muitos pontos a serem corrigidos. Alguns elementos de contrevérsias foram sinalizados, dentre eles destacaram-se:

- a manutenção dos recursos fornecidos;

- a continuidade dos programas implementados;

- as contradições entre incentivo à colaboração e punição por produção não condizente com os critérios estabelecidos pelas agências de fomento e pontuado como bipolaridade das políticas públicas;

- políticas propositivas no que se refere à colaboração mas penalizantes nas avaliações individuais e/ou dos programas de pós-grraduação.

Infere-se, entretanto, que apesar dos pontos de insatisfação apontados e passíveis de solução, a política pública representada pelo Programa INCT vem cumprindo o que foi planejado e conseguindo avanços referentes à pesquisa, formação de recursos humanos e transferência de conhecimento científico e tecno- 
lógico. A infraestrutura fornecida pelos INCTs, apesar de não estar alinhada ao modelo de infraestrutura $e$-Science, está cumprindo com o seu papel de suporte para a realização das pesquisas científicas e tecnológicas envolvidas no seu conglomerado.

O Programa INCT está interferindo de modo significativo nos resultados da produção científica nacional, com impacto quantitativo e qualitativo. A colaboração realizada entre os pesquisadores foi até utilizada como moeda de troca entre esses e as instituições sede. Conforme se pode constatar, a seguir, no relato dos coordenadores sobre a questão:

impactou não só do ponto de vista quantitativo, mas do ponto de vista qualitativo também. $\mathrm{O}$ impacto quantitativo foi muito alto. Só para você ter uma ideia alguns colegas, por exemplo, [...], se você entra no Lattes deles antes do início do INCT, são ex-alunos nossos que foram para lá, se você entra no Lattes deles antes vê pouquíssimas publicações e não tinham publicação, depois que foram para lá. Quando nós começamos os INCT você pega a publicação deles e eles publicam pelo menos dois, três artigos por ano. Seria muito difíil eles fazerem isso sem o INCT;

fora que abriu outras oportunidades, o fato deles estarem no INCT, por exemplo, os colegas do [...], eles usaram isso como moeda junto a universidade. Nós precisamos de laboratórios e a universidade construiu laboratórios para eles, conseguiu emendas parlamentares para colocar recursos dentro do laboratório, ou seja, é uma bola de neve, só tende a favorecer todo mundo;

claro que tem grupos que não cumprem o que prometem infelizmente, mas a grande maioria sim, a grande maioria veste a camisa e as coisas dão muito certo para todo mundo.

E, apesar dos problemas detectados, pertinentes às políticas de governo, que sofrem com as constantes interrupções em virtude das troca de forças dominantes no poder e quebra de continuidade dos programas implementados, por alguns governantes que assumiram os novos mandatos, estão conseguindo sobreviver. A questão que cercou a incerteza sobre a continuidade do Programa INCT foi uma das causas de preocupação dos coordenadores dos institutos analisados, cujos depoimentos foram registrados em algumas passagens desta seção. Observações direcionadas às questões particulares, que cercam toda problemática foram alvo de novos relatos dos coordenadores, conforme relatos apresentados no Quadro 21. 
Quadro 21 - Panorama político - INCTs

\begin{tabular}{|l|}
\hline \multicolumn{1}{|c|}{ PANORAMA POLíTICO - INCTs } \\
\hline [...] a verdade é que este governo atual tem sido bastante negativo para os INCTs. Você vê que \\
no governo do Lula por exemplo, eu não sei se por conjuntura ou por ser uma política própria, \\
os INCTs foram muito apoiados, mas nos quatro últimos anos e agora no novo governo da \\
Dilma, ela desprezou completamente os INCTs, espero que haja alguma mudança no novo \\
edital, mas o edital era para ser julgado em 2015, mas já foi empurrado para 2016.
\end{tabular}

[...] eu não vejo o INCT como uma política pública porque se fosse uma política pública teria tipo uma continuidade e uma coisa que na vida inteira eu não vejo nenhuma diferença, você faz um projeto grande, um grande investimento como foi feito anteriormente no PRONEC, depois teve os Institutos do Milênio etc e da um grande volume de recursos, todo mundo fica feliz, depois não tem mais recursos para manter o investimento inicial feito. Não precisa ficar investindo toda hora, mas você tem que no mínimo manter o investimento que foi feito. Não mantém nada e tudo fica obsoleto, depois vem um outro programa e dai você renasce das cinzas e a cada cinco ou seis anos você tem que renascer das cinzas e na realidade por enquanto, os INCT estão no mesmo barco.

claro, definitivamente, e nos diminuímos é uma questão de visão muito restrita dos nossos governantes. E não é desse governante ou daquele governante, é no geral mesmo, no geral. Eu não sei se eu deveria falar isso, mas eu só vi um governante que levou muito a sério e que acreditava, foi o governo Lula e, veja bem, não foi o PT não foi o governo Lula. É diferente e do meu ponto de vista são duas coisas bem distintas, porque no governo Dilma..., no governo Lula ele nunca rifou a Ciência e Tecnologia ele sempre colocou pessoas sérias. No governo Dilma ela já entrou colocando o Mercadante como ministro da Ciência e Tecnologia, é rifar mesmo e por aí você vê que isso é uma questão de prioridade, você não acha que aquilo é uma coisa importante, apesar do discurso certo, tem o discurso, mas a prática está....

uma política pública, o sentido do termo política publica para mim é uma coisa de longo prazo que você investe na manutenção de um modelo e isso na realidade não foi feito, tanto não foi feito que o dinheiro dos INCT terminaram foi, solicitada projetos novos para renovação ou novos para criação de novos INCT e na realidade a mais de um ano que estão adiando, adiando e adiando e sabe Deus quando que de fato vai ter recursos.

Fonte: Elaboração da autora.

Um cenário conturbado e recheado de incertezas em relação à perpetuação de uma política pública, que em termos de resultados efetivos e correspondência às exigências realizadas foi plenamente satisfeito. O Programa INCT publicou o resultados das chamadas realizadas e ofereceu aos seus associados um motivo para 
respirar com um pouco mais de tranquilidade e ter esperança na continuidade de um empreendimento de peso, que somente o tempo poderá atestar o desfecho.

As evidências que comprovaram as práticas colaborativas, a produção científica e a causalidade da $e$-Science como modelo de fomento para as pesquisas no Brasil foram contempladas na seção seguinte. 